OPEN ACCESS

Edited by:

Qing-Wu Yang,

Xinqiao Hospital, China

Reviewed by:

Zhe-Qi Xu,

Second Military Medical University,

China

Shuangchan Wu,

Northwestern Polytechnical University,

China

*Correspondence:

Sajjad Muhammad

sajjad.muhammad@med.uni-

duesseldorf.de

orcid.org/0000-0002-6734-7979

Specialty section:

This article was submitted to

Multiple Sclerosis

and Neuroimmunology,

a section of the journal

Frontiers in Immunology

Received: 28 July 2021 Accepted: 15 September 2021

Published: 07 October 2021

Citation:

Shaheryar ZA, Khan MA, Adnan CS, Zaidi $A A$, Hänggi $D$ and Muhammad $S$

(2021) Neuroinflammatory Triangle

Presenting Novel Pharmacological

Targets for Ischemic Brain Injury.

Front. Immunol. 12:748663.

doi: 10.3389/fimmu.2021.748663

\section{Neuroinflammatory Triangle Presenting Novel Pharmacological Targets for Ischemic Brain Injury}

\author{
Zaib A. Shaheryar ${ }^{1,2}$, Mahtab A. Khan ${ }^{3}$, Ch. Sherjeel Adnan ${ }^{2}$, Awais Ali Zaidi ${ }^{2,4}$, \\ Daniel Hänggi ${ }^{6}$ and Sajjad Muhammad ${ }^{5,6 *}$ \\ ${ }^{1}$ Institute for Experimental and Clinical Pharmacology and Toxicology, University of Lübeck, Lübeck, Germany, ${ }^{2}$ Faculty of \\ Pharmacy, University of Lahore, Lahore, Pakistan, ${ }^{3}$ Faculty of Pharmacy, University of Central Punjab, Lahore, Pakistan, \\ ${ }^{4}$ Imran Idrees College of Pharmacy, Lahore, Pakistan, ${ }^{5}$ Department of Neurosurgery, University of Helsinki and Helsinki \\ University Hospital, Helsinki, Finland, ${ }^{6}$ Department of Neurosurgery, Faculty of Medicine and University Hospital Düsseldorf, \\ Heinrich-Heine University Düsseldorf, Düsseldorf, Germany
}

Ischemic stroke is one of the leading causes of morbidity and mortality globally. Hundreds of clinical trials have proven ineffective in bringing forth a definitive and effective treatment for ischemic stroke, except a myopic class of thrombolytic drugs. That, too, has little to do with treating long-term post-stroke disabilities. These studies proposed diverse options to treat stroke, ranging from neurotropic interpolation to venting antioxidant activity, from blocking specific receptors to obstructing functional capacity of ion channels, and more recently the utilization of neuroprotective substances. However, state of the art knowledge suggests that more pragmatic focus in finding effective therapeutic remedy for stroke might be targeting intricate intracellular signaling pathways of the 'neuroinflammatory triangle': ROS burst, inflammatory cytokines, and BBB disruption. Experimental evidence reviewed here supports the notion that allowing neuroprotective mechanisms to advance, while limiting neuroinflammatory cascades, will help confine post-stroke damage and disabilities.

Keywords: neuroinflammation, blood brain barrier, cytokine, brain microvascular endothelial cell, reactive oxidative species

\section{HIGHLIGHTS}

This review article highlights important cellular and subcellular targets for stroke, and might aid the scientific community in deeply understanding and targeting one or more these targets, to develop clinical therapeutic interventions in stroke.

\section{INTRODUCTION}

Stroke follows heart diseases and cancer as the highest global cause of mortality. It is the leading cause of permanent disabilities (1). Stroke is generally classified into hemorrhagic and ischemic, with the latter involved in about $85 \%$ of stroke accidents (2). Hemorrhagic stroke underscores the rupture of intracranial aneurysm (ICA), dural arteriovenous fistula (dAVF), cerebral arteriovenous 
malformation (AVM), or rupture of small vessel due to hypertension, while ischemic stroke represents embolic or thrombotic occlusion in a brain artery $(3,4)$. In either of these cases, the repercussions are brain-tissue injury and functional disabilities due to damage to the respective brain region (5). The instant and primary damage to the brain cells are followed by neuroinflammatory cascade entailing bursts of reactive oxygen species (ROS), release of a variety of signaling cytokines, and damage to the cerebral microvasculature, as well as disruption of the blood-brain barrier (BBB) (6-9). These molecular neuroinflammatory mechanisms potentiate damage to the brain cells and influence the clinical outcome.

Neuroinflammation comprises of complex cellular and subcellular mechanisms triggered in response to injury in brain cells (10). The main driving factor for the carrying out of neuroinflammation is the bid to root out the damaging stimulus, however, once initiated it might become over activated, spreading initially to the damaged brain regions and initiating a range of intricate signaling pathways that advance the neuroinflammation to the next level $(11,12)$. In acute phase, the damaged neuronal cells and resident immune cells secrete inflammatory mediators including cytokines, free radicals, and prostaglandins to signal other inflammatory fragments (13). In response, neighboring glia and microglia are activated which further secrete chemical mediators to make arrangements for the disruption of the blood brain barrier and invite immune cells from systemic circulation to expand the scope of neuroinflammation (14). The ROS burst, cytokines, related subcellular pathways, and disrupted $\mathrm{BBB}$ all contribute to inflammation-mediated tissue damage (15). This triangle of ROS, cytokines, and $\mathrm{BBB}$, is the most simplified concept in understanding how neuroinflammation advances brain injuries, particularly after stroke.

\section{CYTOKINE-RELATED PATHWAYS IN THE NEUROINFLAMMATORY TRIANGLE}

Following ischemic stroke, damaged neurons, regional microglia, and astrocytes become the repository of initial stimuli for neuroinflammation. Microglial cells are a specialized population of macrophages that are resident in the brain and spinal cord (16). They do not inhabit a particular location, but rather advance to different areas in order to clear the debris of dead neurons, maintain tissue homeostasis, phagocytose infiltrating pathogens or necrotic cells, release immune factors that are either inflammatory or regulatory, and facilitate the repair process in damaged parts of the brain provoked by mediators released in the vicinity (17-21).

After the onset of ischemic stroke, it takes no longer than a few minutes to initiate the neuroinflammatory cascade (10). As soon as the microglial cells are activated, they not only change shape (morphological transformation) and polarize into special phenotypes, but also kickstart inflammatory signaling pathways (22).

Traditional approaches have classified activated brain microglia into two key sub-populations: M1 and M2 (23). To which phenotypic population they will switch to depends upon the nature and intensity of the stimuli $(24,25)$. M1 microglia are referred to as "pro-inflammatory" cells as they aggravate neuronal damage in ischemic brain regions along with disrupting the $\mathrm{BBB}$ to varying extents $(26,27)$. The compromised $\mathrm{BBB}$ subsequently allows infiltration of systemic leukocytes at the site of ischemic insult, expending the inflammatory cascade and neuronal damage (16). The reported pro-inflammatory mediators released and their respective pathways are discussed under separate headings below.

\section{Pro-Inflammatory Mediators Released by M1 Phenotype of Microglial Cells}

Multiple proinflammatory cytokines are released by M1-type microglia that determine the tissue damage. Here, we review the most important cytokines released from the M1- type of microglia.

\section{Tumor Necrosis Factor}

TNF is a well-known proinflammatory cytokine that mediates tissue damage after stroke through multiple mechanisms. When TNF was administered directly to the brain parenchyma, it elicited local microvascular injury in the form of pericapillary edema (28) and leukocyte adhesion to cerebral capillaries (29). Similarly, when TNF was administered into the cerebroventricular space prior to ischemia, it augmented the extent of tissue damage, expanded the otherwise average infarct volume, and aggravated neurological deficits (30). These facts highlight the pro-inflammatory potential of TNF in brain ischemia. TNF mediates a neurodegenerative cascade through interferon receptors (INFRs) which are present on infiltrating macrophages, T-lymphocytes, glia, and neurons (31). TNF modulates gene expression via simple, direct signaling pathway resulting in secretions of pro-inflammatory mediators by these cells (32).

TNF released by activated microglia within the ischemic area of the brain binds to two types of receptors, namely TNFreceptors 1 (TNFR1) and TNF-receptor 2 (TNFR2) (33). The role of TNFR1 as well as its extended relationship with neurodegenerative outcomes have been well established. The activation of TNFR1 begins when the trimeric TNF binds to the trimeric receptor complex (Figure 1) (34). This triggers a complex formation with several adapter proteins, such as TNFreceptor-associated death domain (TRADD) and Fas-associated death domain (FADD). These adaptor proteins bind with the intracellular part of TNFR1, which consists of the 80-amino acid death domain (DD). The point at which the adaptor proteins bind is important (35).

We refer to this as the bifurcation point, as it will decide on the nature of signaling and further cell fate. Cell death signals will prevail if binding adapter proteins are Fas-associated protein and caspase- 8 (that is probably the reason why caspase inhibitors reduce ischemic injury) (36). On the other hand, the inflammatory messages will be produced via expressing relevant genes when these adapter proteins are receptorinteracting protein kinase 1 (RIPK1) (leading to nuclear factor $\kappa \mathrm{B})$ or c-Jun N-terminal kinase (JUN) $(37,38)$. Consequently, infiltrating cells synthesize adhesion molecules and release IL-1, nitric oxide, and plasminogen activator inhibitor-1 (39). All these 


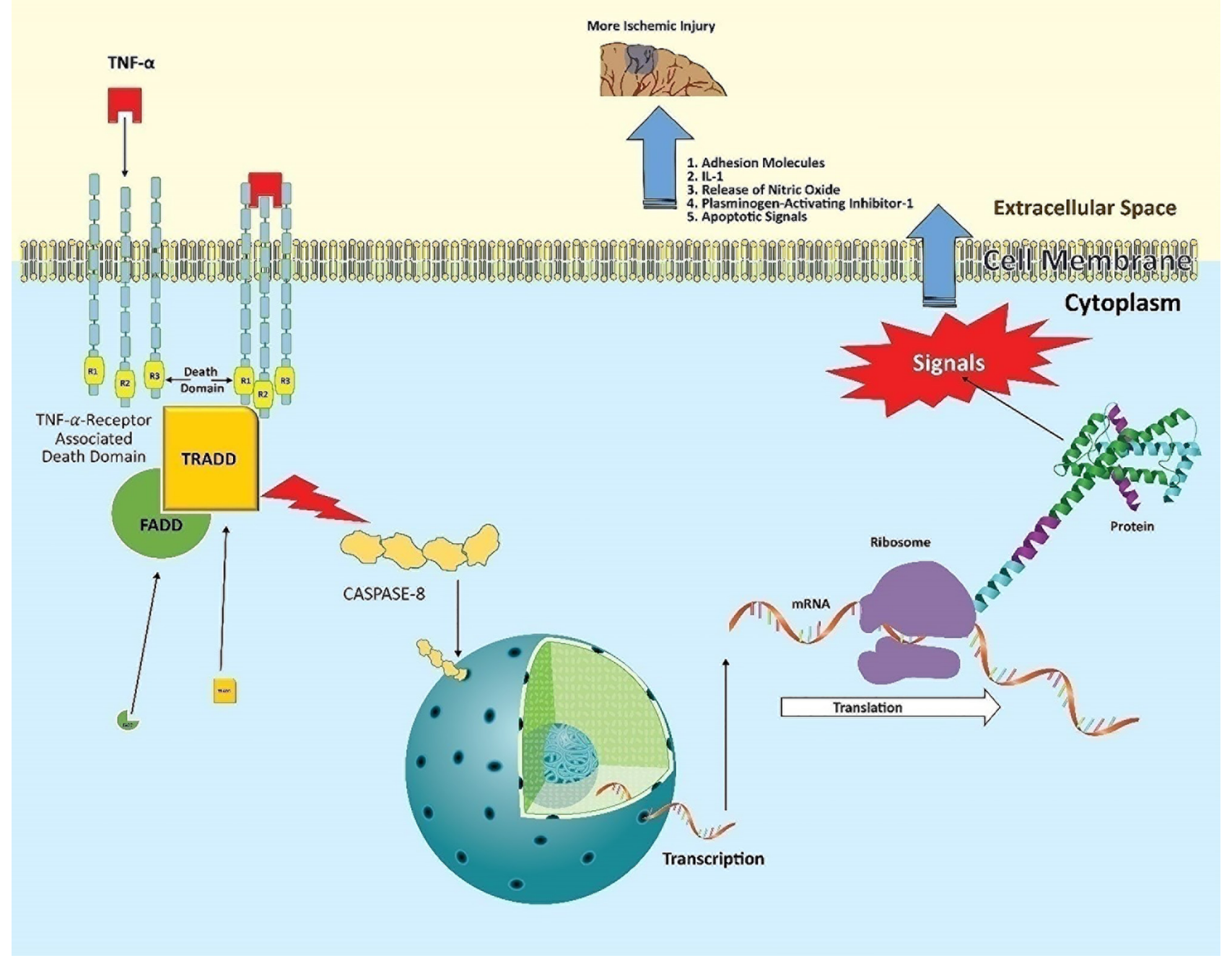

FIGURE 1 | Post-stroke neuroinflammatory pathway of TNF. TNF released from activated microglia binds to the trimeric TNFR1, primarily present on infiltrating leukocytes. This allows the intracellular part of the receptor to complex with the adaptor proteins TRADD and FADD via its death domain. This domain activates cytoplasmic caspase-8 enzyme. Activated caspase-8 acts as a transcriptional factor, entering the nucleus to induce target genes. The expressed mRNA encodes proteins such as adhesion molecules, IL-1, nitric oxide synthase (nNOS), plasminogen-activating inhibitor-1, and apoptosis-inducing factors. This 'mix' contributes to the neuronal damage in ischemic tissue following stroke.

factors directly participate in neuronal degeneration and expanding stroke volume.

Apoptosis is a distinct form of cell death that is functionally and morphologically different from necrosis. Nuclear chromatin condensation, cytoplasmic shrinking, dilated endoplasmic reticulum, and membrane blebbing characterize apoptosis in general.

\section{Interleukin-1 $\beta$}

Experimental studies show that the major form of IL-1 contributing to ischemic injury is IL- $1 \beta$ (40). In one study, chronic deletion of IL- $1 \beta$ receptors failed to deteriorate ischemic brain damage, employing the neurotoxic potentials of IL-1 $\beta$ via their receptors (41). IL-1 proteins are thus key players in signaling pathways such as apoptosis, toll-like receptors
(TLRs), mitogen-activated protein kinase (MAPK), NOD-like receptors (NLRs), and nuclear factor $\kappa$-light-chain-enhancer of

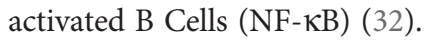

The IL-1 family consists of eleven isoforms, out of which IL$1 \alpha$ and IL- $1 \beta$ play a strong pro-inflammatory role in neurodegenerative diseases (42). Another member of this family is the endogenous IL-1 receptor antagonist (IL-1Ra). In neurodegenerative diseases, IL- $1 \beta$ is considered one of the main culprits for infiltration of neutrophils, shattering of the $\mathrm{BBB}$, astrogliosis, and neovascularization $(43,44)$. Support for this concept was obtained by employing the IL- $1 \beta$ antagonist on brain tissues. This significantly limited brain lesions as well as excitotoxic damage in rats (45).

IL-1 produced by neurovascular endothelial cells, resident microglia, astrocytes, and infiltrating macrophages binds to IL-1 
receptor type 1 (IL-1R1), localized in the cell membrane of all brain cells except microglia (46). Described in Figure 2, IL-1 $\beta$ is initially formed as a precursor protein, which is then cleaved and activated by caspase 1 , followed by its release. The mature form of IL- $1 \beta$ forms a complex with transmembrane IL- 1 receptor with the help of an accessory protein called IL-1 receptor accessory protein (IL-1RAcP) (47).The ligand-receptor complex triggers recruitment of various cytoplasmic proteins leading to multifarious intracellular signaling pathways guided by selfpropagating cascades, namely deacetylation, phosphorylation, ubiquitination, methylation and palmitoylation, subsequently initiating three key neuroinflammatory mechanisms (48). The first key mechanism is the activation of NF- $\kappa B$, second, the initiation of the c-Jun N-terminal kinases (JNKs) pathway, and third, the triggering of the p38 mitogen-activated protein kinase (P32 MAPKs) pathway $(30,49,50)$.

In the first mechanism, NF- $\kappa B$ leads to the synthesis of neurotoxic or inflammatory mediators like TNF and diverse chemokines, collectively causing aggravated brain damage along with astrogliosis (51). NF- $\mathrm{KB}$ is a protein complex that controls gene expression in response to extracellular signals. This complex contains five structurally similar members: p50, p52,

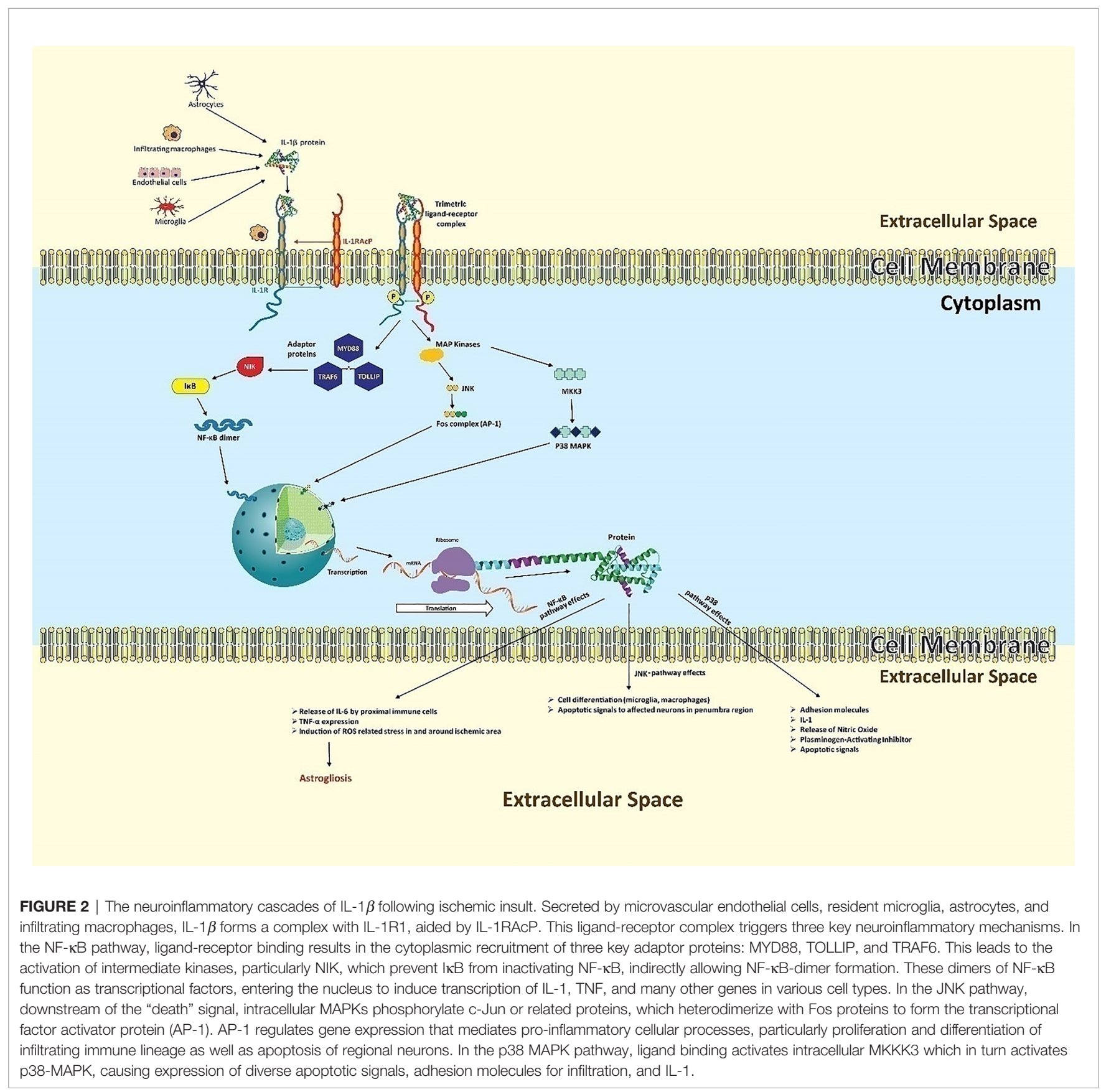


p65, c-Rel, and RelB (52). These proteins form NF- $\kappa B$ dimers to induce or, rarely, repress target genes (53). Depending on the ligand-receptor complex, various adaptor proteins are recruited and determine which type of message is to be transduced. For the activation of $\mathrm{NF}-\kappa \mathrm{B}$, upstream signaling proteins include myeloid differentiation primary response 88 (MYD88), toll interacting protein (TOLLIP), and tumor necrosis factor receptor-associated factor 6 (TRAF6) (54). The recruitment cascade ultimately leads to activation of intermediate kinases such as interleukin-1 receptor-associated kinase (IRAK), receptorinteracting proteins (RIP), and NF- $\kappa \mathrm{B}$ inducing kinase (NIK) (55, 56). In a normal biological state these intermediate kinases activate a biological complex called inhibitor of kappa B (IאB) (57), which inactivates NF- $\kappa B$ in cytoplasm to prevent gene expression. However, in a diseased or stress state (stroke), these I $\mathrm{B}$ are phosphorylated, ubiquitinated, and then degraded. In the absence

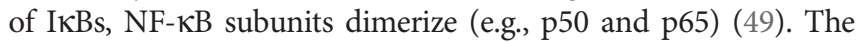
dimers translocate to the nucleus as a transcriptional complex.

In the second mechanism, the ligand-receptor complex activates c-Jun N-terminal kinases (JNKs) which exert the "death" signaling (58). The JNKs (JNK1 and JNK3) belong to the family of mitogen-activated protein kinases (MAPKs) that phosphorylate several proteins including the intracellular c-Jun protein which further heterodimerizes with Fos proteins (59). The complex of c-Jun and Fos protein is called transcriptional factor activator protein (AP-1) that regulates gene expression for pro-inflammatory cellular processes including proliferation and differentiation of infiltrating immune lineage as well as apoptosis of regional neurons (60-62).

In the third mechanism, the ligand-receptor complex activates mitogen-activated kinase kinase kinase-3 (MKKK3) which in turn activates p38-MAPK $(63,64)$.

The three transcription factors NF- $\mathrm{B}, \mathrm{AP}-1$, and $\mathrm{p} 38-\mathrm{MAPK}$ help in modulating the gene expression for the desired biological response in the neuronal environment. The final outcomes of these expressions are manifested in the form of more inflammatory damage in the brain.

The intracellular and subcellular changes stimulate the expression of genes, which become key pro-inflammatory mechanisms. The JUN and p38 MAPK pathways, in parallel, induce the expression of genes for IL-6, IL-8, PCP1, COX-2, IL$1 \beta$, and MKP-1 (60).

The more IL $-1 \beta$ is expressed and released, the more other pro-inflammatory mechanisms will be activated.

\section{Interferon Gamma}

Apart from a variety of influential biological functions, IFN- $\gamma$ (sourced by resident astrocytes as well as infiltrating $\mathrm{T}$ lymphocytes) up regulates the expression of class II major histocompatibility complex (MHC) molecules on the surface of macrophages and other T cells in brain tissues, which find their way through the disrupted $\mathrm{BBB}(65,66)$. Immunohistochemistry and flow cytometric data show that activated $\mathrm{CD} 4^{+}$cells are found in and around the ischemic site with abundant MHC class II molecules on their surface for an effective inflammatory response $(67,68)$. Conversely, IFN- $\gamma$ not only helps polarization of other distant microglial cells, but also influences the differentiation of $\mathrm{CD}^{+}$, which further produces pro-inflammatory cytokines like IL-2, IFN$\gamma$, and TNF $(69,70)$. Direct injection of IFN- $\gamma$ into the rat CNS induced inflammation and cellular infiltration similar to that observed in chronic neurological diseases (71). This was indirectly evaluated by injecting IFN- $\gamma$ in IFNGR-deficient mice (72). The results signified a lack of integrity and preservation of BBB.

In another mechanism, IFN- $\gamma$ up-regulates the expression of IFN- $\alpha$ in microglial cells around the ischemic core, suppressing the neuroprotective role of microglia (73).

IFN- $\gamma$ in the CNS facilitates helper $\mathrm{T}$ cell infiltration and neuroinflammation by inducing expression of vascular cell adhesion molecule 1 (VCAM-1), intercellular adhesion molecule 1 (ICAM-1), the chemokines CCL2 (recruits monocytes, memory T cells, and dendritic cells to the infarct area), CXCL9 (chemokine ligand 9 belonging to CXC chemokine family and induces chemotaxis, promotes differentiation and proliferation of leukocytes, and causes brain edema), and CXCL10 (secreted by infiltrating monocytes and endothelial cells in response to IFN- $\gamma$ ) (74-79).

Adding to the damage, IFN- $\gamma$ increases the expression of MHC class II and co-stimulatory molecules on microglial cells (particularly M1 subtype), helping them act as antigen-presenting cells (APCs) for infiltrating myelin-specific $\mathrm{T}$ cells and leading to inflammation and demyelination $(80,81)$. One important thing to highlight here is the fact that increased concentrations of IFN- $\gamma$ impairs the neuroprotective potential of M2 polarized microglial cells in severe inflammatory brain diseases (82).

By another mechanism, IFN- $\gamma$ binds to INFRs located on neurovascular endothelial cells and immune cells to upregulate the expression of transmembrane intracellular adenosine molecule type-1(ICAM-1), resulting in infiltration of immune cells through the compromised BBB. IFN- $\gamma$ also induces the gene expression of the vascular cell adhesion molecule (VCAM-1) on primary astrocytes, thereby further enhancing their role in inflammation $(83,84)$.

IFN- $\gamma$ acts by binding and signaling via interferon gamma receptors (INFGR), which are overly expressed during inflammatory conditions in the brain (Figure 3) (85). IFNGR1 and INFGR2 consist of two different protein subunits (86). Both receptors are not in proximity to each other until IFN- $\gamma$ binds to the extracellular domain of INFGR1 and triggers the cascade (87). Inside the cell, each subunit of IFNGR1 and INFGR2 is attached to a unique member of the Janus family kinase family (Jaks), i.e., Jak1 and Jak2, respectively (88). As soon as IFN- $\gamma$ binds to the extracellular domain of IFNGR1, it brings IFNGR1 and INFGR2 in close proximity, clearing the way for the point where IFN- $\gamma$ binds with IFNGR1 and INFGR2. Subsequently, Jak1 and Jak2 phosphorylate each other on each receptor domain. Phosphorylated sites become docking points for an intracellular transducer and activator of transcription (STATs). This will result in phosphorylation of STATs by respective JAKs. The activated STAT1 dissociates and forms a homodimeric complex and travels to the nucleus where it binds to its genes to induce transcription $(89,90)$.

By such signaling, IFN- $\gamma$ participates in modulating gene expression in microglia and astrocytes (91). Elevated levels of 


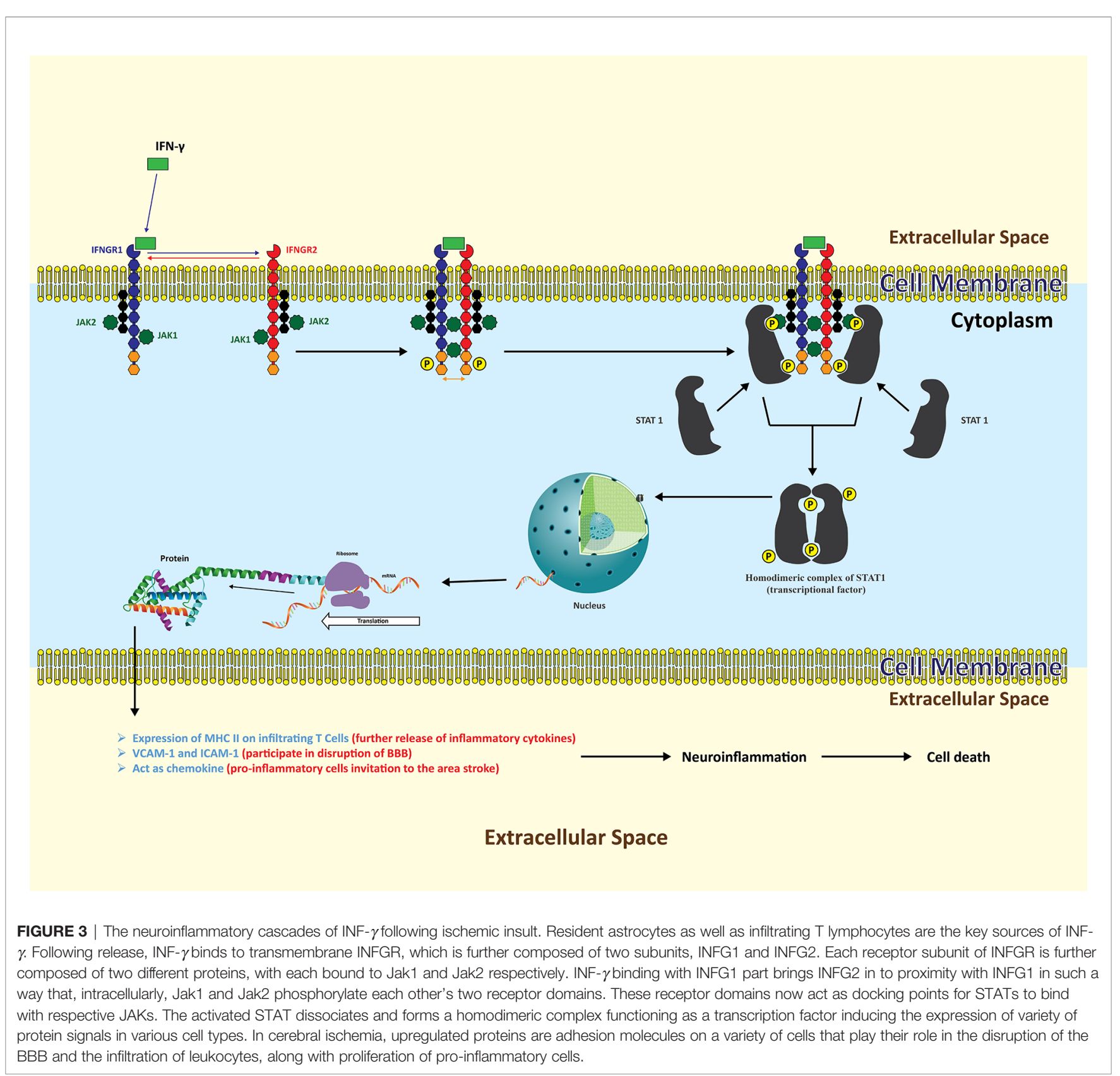

MHC II and ICAM-1 (intracellular adhesion molecule type 1) on the surface of these cells transform the pathophysiological environment suitable for infiltration of leukocytes, release of inflammatory cytokines, and enlargement of stroke lesions (92).

Despite various new studies exploring interactive effects of IFN- $\gamma$, it is becoming evident that this cytokine not only has protective effects but also well proven proinflammatory and deleterious consequences in the brain $(89,93)$.

\section{Interleukin 6}

A major proinflammatory cytokine which is implicated in the expansion of ischemic volume is interleukin 6 (IL-6) (94). Diverse stroke studies underscored the significant increase in the levels of
IL-6 immediately after stroke onset $(95,96)$. Many of these studies implicate IL- 6 as a key contributing factor in the pathogenesis of ischemic stroke, however, some of the research studies faintly underscore the contrary. Taking the convincing evidence, IL-6 is being discussed here as a neuroinflammatory protein.

Resident microglia, endothelial cells of the cerebral circulatory system, and infiltrating macrophages and $\mathrm{T}$ cells are fundamental sources of its release (97-99). It acts as a messenger protein between leukocytes, endothelial cells, and parenchymal cells (100). The pathophysiological manifestations produced in response to IL-6related signaling mechanisms are multifaceted and complex. However, various studies have pointed to some key effects of IL-6: proliferation of infiltrating immune cells, expression of genes 
related to growth inhibitory proteins, and apoptosis-inducing endogenous secretions $(28,101,102)$. These conclusively add more to the neuroinflammation and its deteriorating effects.

IL-6 signaling transduction is mediated by the IL- 6 receptor (IL-6R) found on a limited subset of immune cells in the brain including microglia, endothelial cells, and infiltrating T cells (not on oligodendrocytes and astrocytes) (103). The IL-6 receptor is activated via two separate, but related, pathways (Figure 4), the classical and the trans-signaling pathways (104).
The classical pathway (producing neuroprotective outcomes) begins when IL- 6 binds with membrane bound IL-6R. The membrane-bound IL-6R is composed of two subunits: the IL-6R$\alpha$ chain (to which IL- 6 binds) and the assisting transmembrane signaling subunit, glycoprotein 130 (gp130), which is the intracellular signal transducer and abundantly expressed during ischemic stroke $(105,106)$. This gp130-associated signaling utilizes intracellular JAK/STAT signaling pathways (107). In this pathway, the complex of IL-6, IL-6R- $\alpha$, and gp130 results in

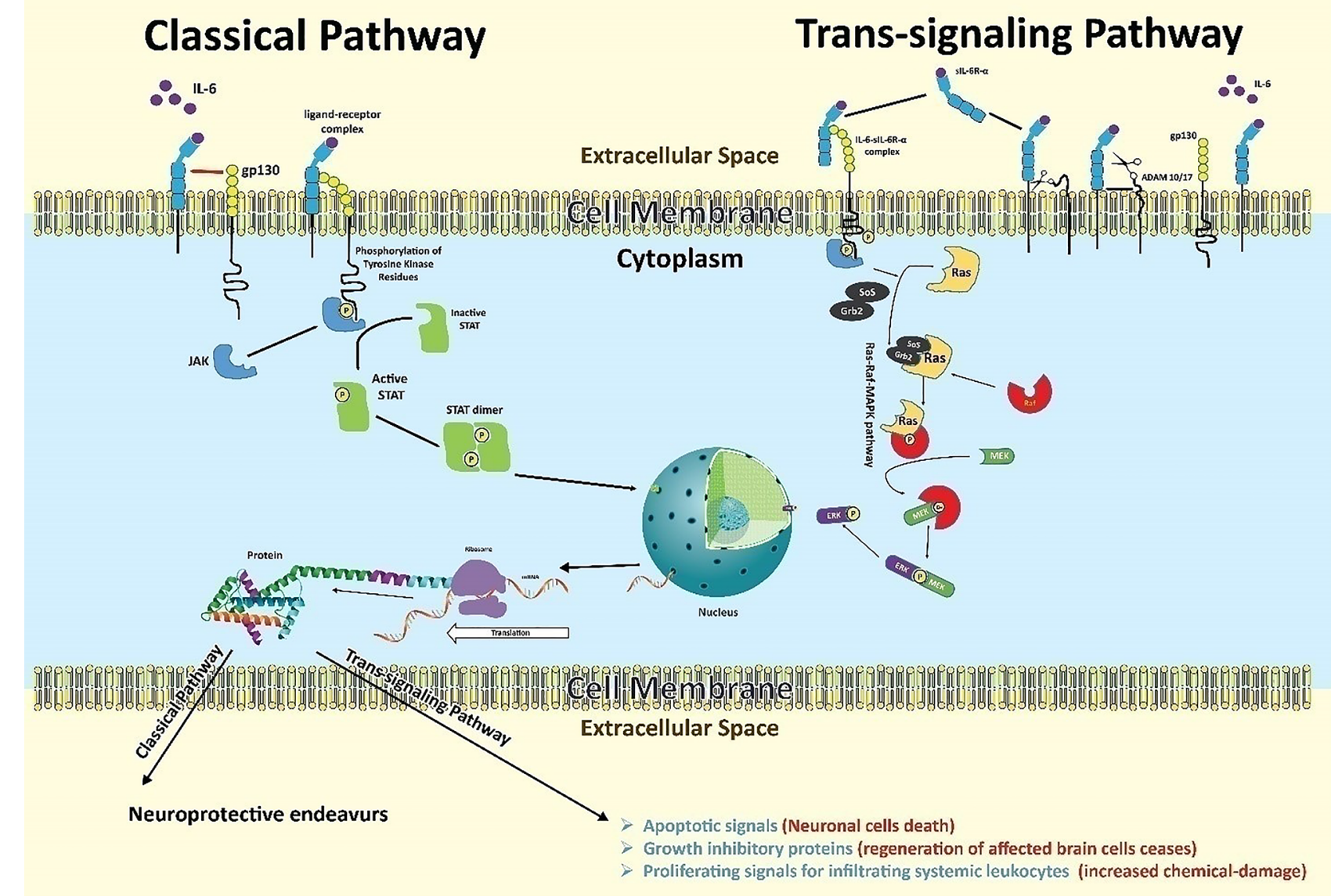

FIGURE 4 | Neuroinflammation downstream of IL-6 in stroke. IL-6 binds its receptor and proceeds two separate but related pathways: the classical and transsignaling pathways. The classical pathway begins when IL-6 binds with IL-6R- $\alpha$ chain subunit assisted by gp130, an intra-cellular signal transducer. This binding allows intracellular, receptor-associated JAKs to phosphorylate each other on respective tyrosine domains. Phosphorylated JAKs further phosphorylate related tyrosine residues on the receptor, creating binding sites for proteins possessing SH2 domains. Cytoplasmic STATs then bind to these SH2 domains to be phosphorylated by respective JAKs, making them dissociate from the receptor. The dissociated STATs form dimers, which act as transcription factors. The dimers translocate to the cell nucleus to induce gene expression for subsequent protein signaling outcomes. STATs may also be tyrosine-phosphorylated directly by receptor tyrosine kinases - but since most receptors lack built-in kinase activity, JAKs are usually required for signaling. The trans-signaling pathway begins when IL6 ligands with sIL-6R- $\alpha$ in the extracellular matrix. The high affinity drives this complex to bind with gp130 expressed overly on glial and neuronal cells following ischemic insult. This trio-binding results in the activation of intracellular tyrosine-associated JAKs. Phosphorylated tyrosine-sited allow the adaptor proteins (SoS and Grb-2) to bind and convert inactive cytoplasmic RAS to an active one, initiating a series of phosphorylations of a variety of molecules like Raf, MEK, and ERK. The activated ERK acts as a transcriptional factor. It enters the nucleus to express targeted genes for inflammatory protein signaling. 
bringing two receptor-associated JAKs (one on each intracellular receptor domain) into close proximity. Each JAK is phosphorylated by the other on a respective tyrosine domain. The activated JAKs in turn phosphorylate related tyrosine residues on the receptor, creating binding sites for proteins possessing $\mathrm{SH} 2$ domains (5). STATs bind to the phosphorylated tyrosines on the receptor using their SH2 domains, and are then tyrosine-phosphorylated by JAKs, causing the STATs to dissociate from the receptor (2). These activated STATs form hetero- or homodimers, where the $\mathrm{SH} 2$ domain of each STAT binds the phosphorylated tyrosine of the opposite STAT, and the dimer then translocates to the cell nucleus to induce transcription of target genes (2). STATs may also be tyrosine- phosphorylated directly by receptor tyrosine kinases; however, since most receptors lack built-in kinase activity, JAKs are usually required for signaling.

In trans-signaling pathway (promote inflammatory outcomes), many cell types in the brain respond to released IL- 6 by releasing a soluble form of IL-6R- $\alpha$ (sIL-6R- $\alpha$ ) in the extracellular environment. Enzymes cut free the sIL-6R- $\alpha$ at the basepoint near the cell membrane (108-110).. This cleavage is done by metalloproteases including A Disintegrin And Metalloproteinase (ADAM) family members ADAM10 and ADAM17 (111). Shedding of the sIL-6R- $\alpha$ allows the free receptor to bind with IL6 ligand in the extracellular matrix. This sIL-6R- $\alpha$ and IL- 6 complex has a very high affinity to membrane bound gp130 (present on the cell membrane of distant glial and neuronal cells), causing activation of intracellular tyrosin-kinases, such as Janus kinase (JAK), which in-turn activates two pathways: activation of JAKSTAT pathway (upregulate the synthesis of iNOS, T cell differentiation)and the RAS-RAF-MAPK pathway (112-114).

Both these mechanisms lead to expression of genes which are associated with producing inflammatory outcomes (115). IL-6 also induces excess production of vascular endothelial growth factor (VEGF), leading to enhanced vascular permeability, which is one of the many pathological features of inflammatory lesions in the brain (116).

\section{ROS BURST IN NEUROINFLAMMATORY TRIANGLE}

Reactive oxygen species (ROS) are a group of reactive oxygencontaining molecules including superoxide, peroxides, single oxygen, and hydroxyl radical $(117,118)$. ROS perform significant physiological roles in diverse biological processes such as intracellular signaling, regulation of transcription, immune response modulation, and apoptosis (119-122).

Under normal physiological conditions in the brain, ROS are produced through two pathways: enzymatic and non-enzymatic pathways (123). Enzymatic pathway is undertaken intracellularly by endogenous enzymes, while non-enzymatic pathway is carried out via antioxidative mechanisms (124, 125). Brain cells entail enzymes such as superoxide dismutase (SOD), glutathione peroxidase (GPX), and catalases (CAT) (126). SOD primarily dismutases superoxide to hydrogen peroxide which is further broken down into water and oxygen by GPX and CAT
(127). In the second pathway, ROS level in the extracellular environment is regulated exclusively by small antioxidant molecules which can be water-soluble or lipid-soluble (128). These antioxidant molecules include Vitamin C, Vitamin E and glutathione, $\mathrm{N}$-acetylcysteine, and melatonin (129, 130). Normally, equation of ROS generation is balanced by the neutralization of ROS by antioxidants (131). Functional roles of ROS at cellular and subcellular levels are unique and diverse.

ROS are central to apoptosis, which in turn is key to maintaining cellular homeostasis like synaptic activity, maintenance of vascular tone, and mediation of inflammatory response (132-134). Apoptotic signaling is translated by ROS through the activation of c-Jun N-terminal kinases and activation of death receptors (135). Similarly, immune cells (microglia and infiltrating macrophages) in the brain are only able to completely digest the engulfed microbes through intracellular oxidative burst $(121,136)$. Also, a variety of cellular signaling in the brain requires ROS for the activation of transcriptional factors like $\mathrm{p} 53$ and NF- $\kappa \mathrm{B}$ for functional outcomes. ROS have a central role to play as second messengers for epidermal growth factor, platelet-derived growth factor (137), and substance $\mathrm{P}$ receptor (138-141).

In the post-stroke phase, the damaged neurons give rise to ROS burst when anti-oxidants fail to maintain this equation resulting in excessive oxidative stress (121). Resultantly, a series of chemical reactions begin where ROS reacts with cellular components of brain cells (142). The more brain cells die, the more the neuroinflammatory effects are.

In a stroke episode, ROS burst causes generalized protein oxidation by disrupting peptide bonds in the amino acid chain, resulting in cross-linkage and denaturation of proteins (Figure 5) (143). Structural alteration in protein molecules causes enzyme inactivation (119) and ion-channel dysfunction (144). One study has demonstrated how protein oxidation causes neurotoxicity by triggering denaturation of glutamine synthetase in mice. In astrocytes, glutamine synthetase transform glutamate to glutamine to protect the neuronal construct against excitotoxicity (145). However, following ischemic stroke, denaturation of various cerebral enzymes fans neuroinflammatory outcomes (27). Lipid peroxidation is another feature of ROS in brain tissues (146).

The phospholipid cell membrane of brain cells is concentrated with fatty acids, particularly polyunsaturated fatty acids. Lipid structures have carbon-carbon double bonds $(\mathrm{C}=\mathrm{C})$ which are the target sites for ROS (147). ROS interaction with $\mathrm{C}=\mathrm{C}$ in lipid molecules produces lipid radicals which further interact with oxygen to make lipid peroxyl radical (148).This lipid peroxyl radical reacts with another proximally available lipid acid to synthesize lipid radical and lipid peroxide (149). These two lipid radicals give rise to highly reactive malondialdehyde (MDA) and (150) (4-HNE), the end products and markers of lipid peroxidation (151). MDA and 4-HNE have devastating effects on neighboring neuronal and non-neuronal cells (152). MDA reacts with enzymatic proteins to form advanced end-products of lipid peroxidation, further contributing secondary deleterious effects in neuroinflammation (153). Parallel to this, 4-HNE chemically reacts with hydroxyl group, aldehyde, and $\mathrm{C}=\mathrm{C}$ in various biological molecular structures to paralyze them functionally (150). It has a 


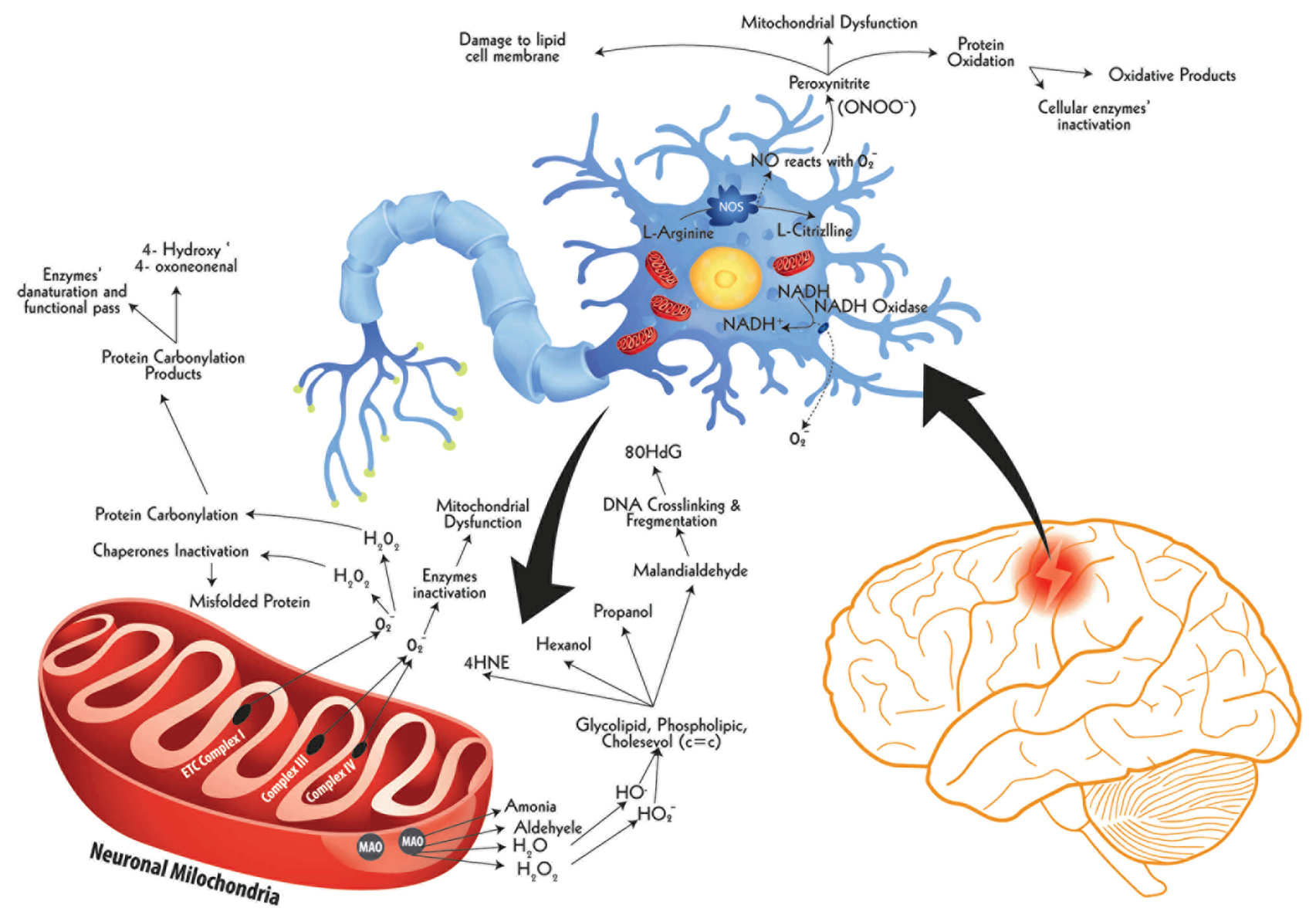

FIGURE 5 | The ROS burst following ischemic insult and damage to biological molecules. Following hypoxia, brain cells witness a swift imbalance between ROS production and their neutralization mechanisms, particularly in neuronal cells, resulting in a constant rise in ROS levels, called ROS burst. One of the key sources of ROS burst inside the cell is mitochondria, others being cell membrane and peroxisomes. These ROS molecules damage cellular parts via protein oxidation, lipid peroxidation, and DNA damage. The neuronal nitric oxide synthase (nNOS) in the cytoplasm of hypoxic neuron produces excessive production of Nitric Oxide (NO) which after release reacts with cellular oxygen producing peroxinitrite (ONOO-), a powerful oxidant damaging cytoplasmic proteins and lipid composites. Another ROS-releasing source during hypoxia is the extracellular space-facing membrane bound enzyme called NADH oxidase. This enzyme releases ample quantities of superoxide molecules with respective damaging implications. A third major source of ROS release is the mitochondria. The external membrane-bound monoamine oxidase (MAO) releases a range of reactive molecules, primarily $\mathrm{H} 2 \mathrm{O} 2$, which causes the production of hydroxyl radical $(\mathrm{HO} \bullet)$ and hydroperoxyl radical ( $\left.\mathrm{HO} 2^{-}\right)$. These two radicals cause lipid peroxidation by selectively attacking carbon-carbon double bond $(\mathrm{c}=\mathrm{c})$ of saturated lipid compounds, releasing by-products such as 4 Hydroxynonenal (4-HNE), Hexanol, Propanol, and Malondialdehyde. Of these, the latter is a highly reactive organic compound, aggressively reacting nucleic material to cause DNA fragmentation. The key DNA fragmentation marker of this pathway is 8 -Hydroxydeoxyguanosine (80HdG). The hypoxia-induced impaired mitochondrial functions, especially affected Complex I, III, and IV, which drive Electron Transport Chain (ETC), release abundant quantities of Superoxides (O2 $\bullet-)$ into the cytoplasm. These superoxides further produce reactive species which have two-fold damaging effects. On the one hand, these inactivate chaperones result in increased levels of misfolded proteins and, on the other hand, cause carbonylation of cellular proteins. This carbonylation of proteins is evident by the elevated levels of carbonylation marker in stroke, such as 4-Hydroxy, 4-oxoneonenal.

direct role to play in advancing neuroinflammatory cascade by acting as a second messenger in the regulation of various transcriptional factors such as erythroid 2-related factor 2, activating protein-1, NF$\kappa B$, and peroxisome-proliferator-activated receptors (154). Various studies have also highlighted the influential role of 4-HNE in MAPK and PI3K/AKT pathways to produce damaging effects following ischemic stroke (155). In one study, vitamin E has demonstrated reduced lesion volume and diminished behavioral impairments in animal MCAO models (156). Also, EPC-K1, a Vitamin C analogue, reduced lesion size in rat MCAO model by limiting lipid peroxidation
(157). Mitochondrial respiratory burst is another major contributory factor in neuronal cell death following stroke, saliently explained in Figure 6 here.

Increased concentration of 8-hydroxy-2'-deoxyguanosine $(8 \mathrm{OHdG})$ is a fundamental marker used by various studies suggesting oxidative DNA damage (158). In the ischemic brain, DNA oxidation suggests DNA disintegration, crosslinking of DNA with denatured protein molecules, as well as DNA mutation (159).

Oxidative stress significantly contributes to the detrimental effects of neuroinflammation. Various antioxidant therapeutic 
approaches, i.e. polyethylene glycol-conjugated SOD (PEGSOD) (160) and polyethylene glycol-conjugated CAT (PEGCAT) (161), underscore that timely interventions following stroke attenuate neuroinflammatory damage partially due to limiting the ROS generation (162).

\section{BLOOD-BRAIN BARRIER IN NEUROINFLAMMATORY TRIANGLE}

The integrity of neurovascular structure is crucial to maintaining a neurophysiological barrier against movement of ions, molecules, systemic immune cells, and subcellular components (163). This barrier is called the Blood Brain Barrier (BBB) and is composed of four key components: brain microvascular endothelial cells (BMEC), Astrocytes, Pericytes, and Microglial cells (164).

BMEC have contrasting features to systemic endothelial cells with closely-fitted junctions to give high ionic transportation, paracellular flux, presence of disproportionately distribution of enzymes, and hermetically sealed carrier-mediated transport system (165). A variety of biological compounds (from glucose to amino acids, and from exogenous drugs to minerals) enter the brain tissue via a special carrier-protein system which is abundantly expressed in BMECs (166). Apart from expressing brain-derived neurotrophic factor $(\mathrm{BDNF})$, transferrin receptor proteins, insulin receptors, and insulin-like growth factor receptor, BMECs also express powerful vasoactive endothelin-1

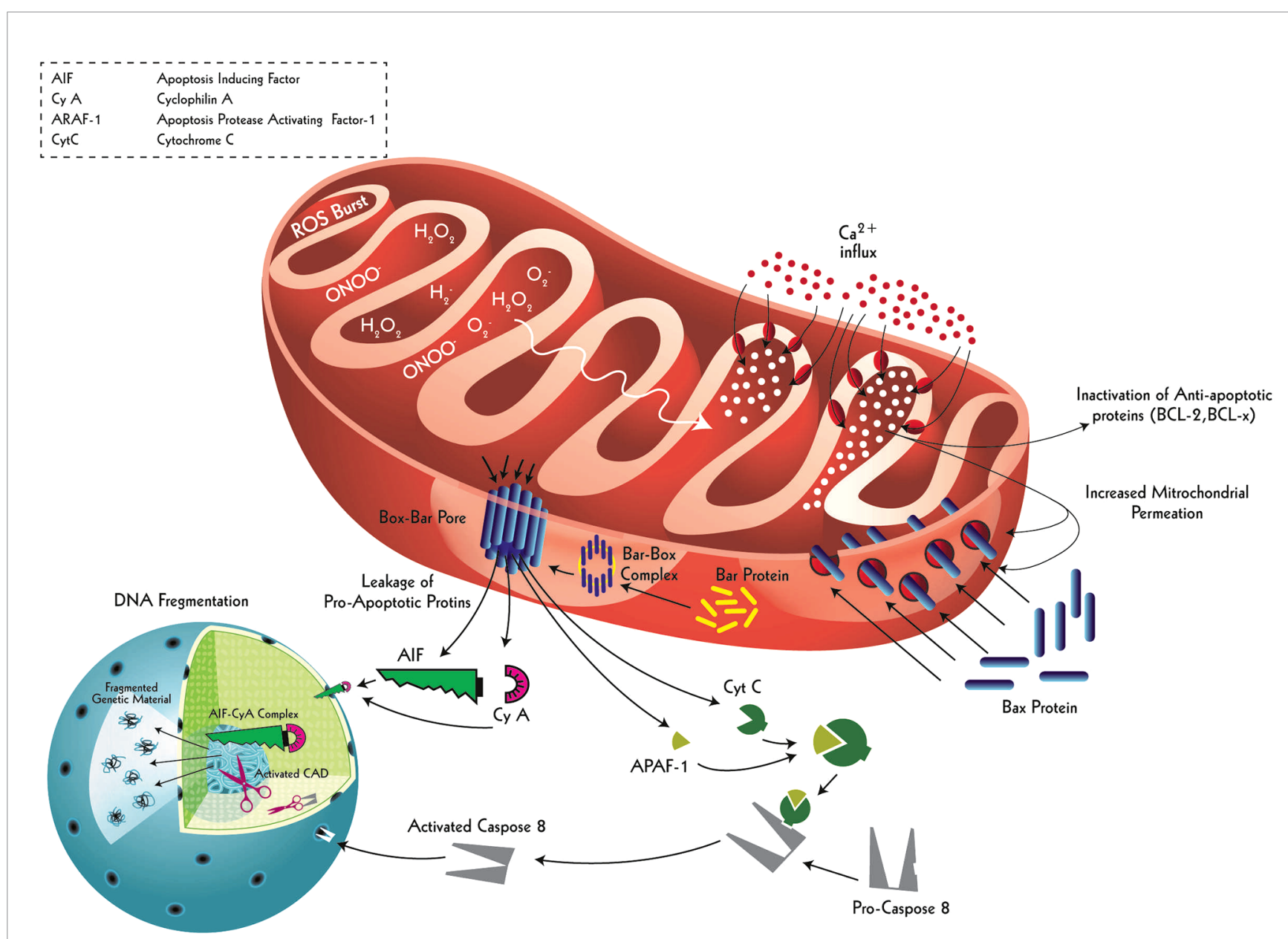

FIGURE 6 | Intrinsic apoptotic signaling and resultant neuronal death driven by ischemic-induced ROS burst. Ischemic events cause mitochondrial matrix of the neurons uptake extracellular calcium as a result of augmented mitochondrial respiratory burst. This calcium accumulation not only causes inactivation of antiapoptotic proteins (BCL-2 and BCL-x) inside mitochondria but also results in an increase in the permeability of the outer and inner mitochondrial membranes. This permeation allows cytoplasmic Bax proteins to enter and make 'tunnel-like' complexes with mitochondrial Bar proteins, which then embed into the outer mitochondrial membrane as Bax-Bar pores. These specialized pores serve as channels to transport intra-mitochondrial pro-apoptotic proteins (AIF, Cy A, APAF-1, and Cyt C) into the cytoplasm. The AIF and Cy A make a complex (AIF-Cy A complex), directly entering the nucleus to inflict defragmentation. Similarly, APAF-1 binds with Cyt $\mathrm{C}$ to transform pro-Caspase 8 protein into an active form: Caspase 8 . The Caspase 8 enters through the nuclear pores to activate Caspase Activated DNase (CAD) which defragments the nuclear material, a key apoptotic signaling outcome. This dual apoptotic signaling effect is primarily initiated by a respiratory burst in the affected neuron following ischemic insult. 
(ET-1; the other less common isoforms are ET-2 and ET-3) and vasodilatory nitric oxide (NO) (167-171).

A balance between ET-1 and NO is crucial for ensuring normal homeostasis in the brain (172). A sudden change in this balance (ischemic stroke) inflicts pathophysiological devastation (173). Expression of ET-1increases in response to ROS burst, neuronal damage, inflammatory cytokines, and thrombin (174).Within a day, the level of ET-1 in Cerebrospinal Fluid (CSF) rises significantly due to astrocytes and endothelial cells which bind numerously expressed ET-1 receptors localized on neurons, glial cells, microvascular endothelial, and smooth muscle cells to give rise to assorted paracrine physiological effects (175-179).

Firstly, ET-1 upsurges the expression of a variety of adhesion molecules from BMECs such as intercellular adhesion molecule 1
(ICAM-1; CD54) (180), vascular cell adhesion molecule-1 (VCAM-1; CD106) (181), and endothelial-leukocyte adhesion molecule 1 (ELAM-1; CD62) (182, 183).

Secondly, ET-1 activates meningeal Mast Cells (MCs) which, upon degranulation, release inflammatory cytokines, playing a contributory role in disrupting BBB (184).

Thirdly, being a powerful vasoconstrictor, it induces longterm blood flow occlusion to the area affected by ischemic insult, thus further fanning neuronal damage, ROS production, and cytokine release (185).

Contrary to this, NO is a minor biological radical which is produced by nitric oxide synthase (NOS) enzyme family from Larginine (186). NOS have three discrete anatomical sources: neuronal NOS (nNOS), inducible NOS(iNOS), and endothelial

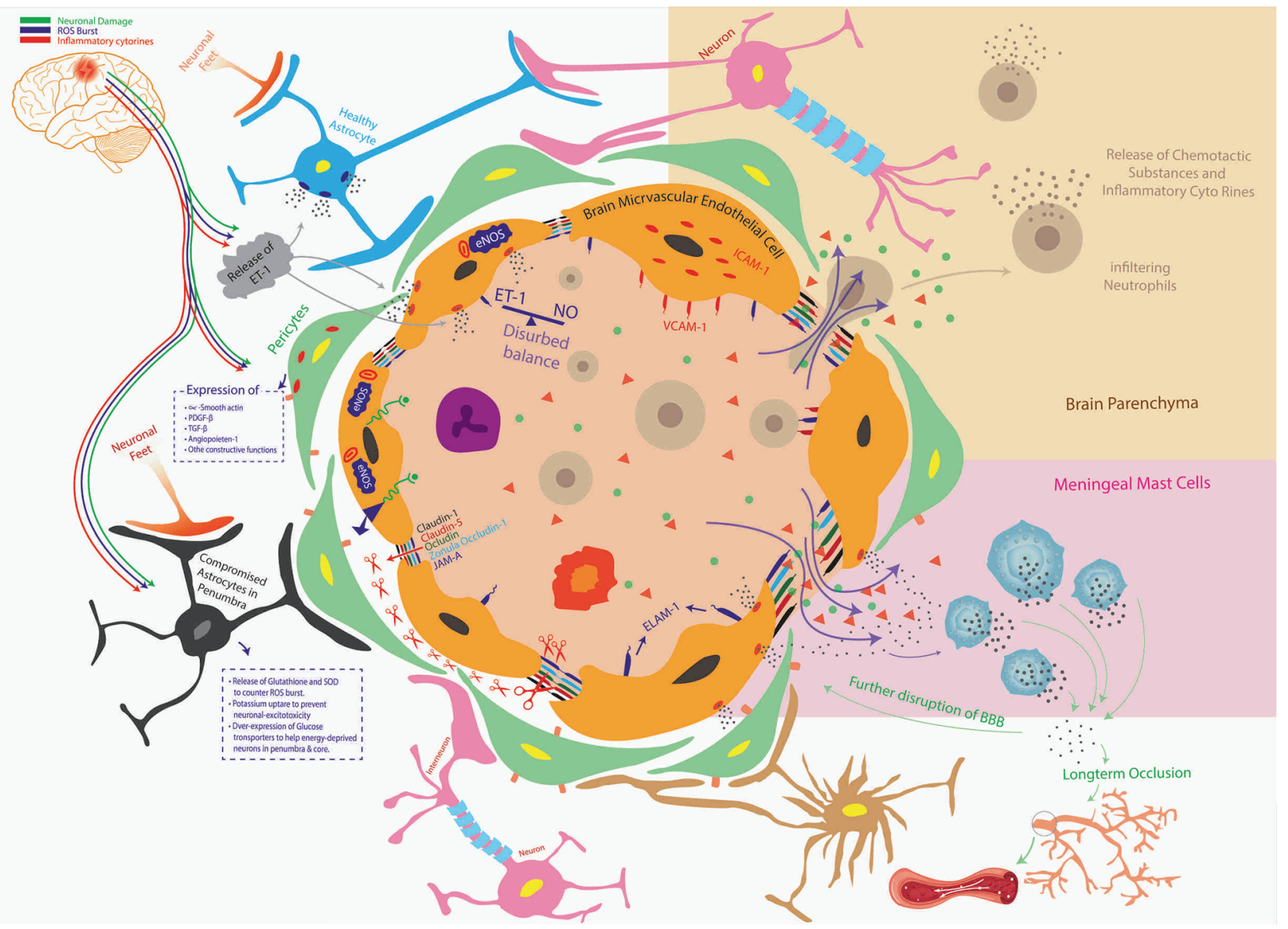

FIGURE 7 | Ischemic stroke and orderly compromisation of BBB. The brain microvascular endothelial cells (BMECs), Astrocytes, Pericytes, and Microglial cells make BBB. Compromised BBB integrity is the striking preliminary feature of the neuroinflammatory-triangle during the hypoxic pathophysiological state, where astrocytes in penumbra, pericytes, and BMECs start releasing ET-1 (disturbed balance of ET-1 and NO). This leads to the upsurge in the expression of a variety of adhesion molecules in/on BMECs such as ICAM-1, VCAM-1, and ELAM-1 to facilitate trans-endothelial migration of leukocytes. ET-1 also upregulates the expression and release of matrix metalloproteinases (MMP) from BMECs which lyse inter-endothelial connecting proteins such as Claudin 1, Claudin 5, Ocludin, Zona ocludin-1, junctional adhesion molecule-A (JAM-A), and others. This compromises the barrier's integrity, otherwise tightly maintained by BMECs, thus allowing the release of inflammatory cytokines, infiltration of systemic immune cells, and fluid escape (brain edema). Inflammatory cytokines stimulate meningeal Mast Cells to release more inflammatory mediators to further the BBB shattering and causing long-term occlusion of blood to already starved brain tissue. Along with BMECs, the functionally compromised Pericytes and Astrocytes in penumbra put their respective neurodegenerative part (crossed red-mark in dotted boxes). The population of infiltrating immune cells and their pro-inflammatory secretions proceeds a vicious neuroinflammatory circle that only aggravates brain edema and infarct volume. 
NOS (eNOS) (187-189). Of these, eNOS have a regulatory role in BMECs (190). Normally, eNOS triggers vasodilation, inhibits platelet aggregation, and revitalizes blood flow to brain tissues; in short, they provide neuroprotective effects (191). This is the other way round in neuroinflammatory cascade where excessive ET-1 production suppresses eNOS expression and further microvascular contraction hinders blood supply to the ischemic site (192).

In this hyper-inflammatory state, BMECs also synthesize enhanced matrix metalloprotein-2 (MMP-2) in response to inflammatory signals (Figure 7) (193) which digest proteins (claudin-1, claudin-5, occludin, and zonula occludens-1) (194) responsible for maintaining tight junctions between endothelial cells, further compromising the BBB integrity (195).

An additional key component of the BBB is astrocyte, which has an inverse relation with neuroinflammatory damage. Following ischemic damage, astrocytes offer recovery back into neurons because they are more resistant to glucose-oxygen deprivation mechanisms (196). Astrocytes release glutathione and SOD in response to ROS burst to reduce oxidative damage and neuronal mortality (197). Apart from this, they enhance potassium uptake to prevent excitotoxicity of neurons following post-stroke extracellular surge in the potassium levels (198). Also, astrocytes overly express glucose transporters to keep the supply of glucose to energy- stressed/dying neurons (199). This is evident by various studies which have found high levels of neuroprotective ethyl pyruvate (a derivative of the energy substrate pyruvate) only when astrocytes proximal to stroked area remain functional (200).

However, impaired astrocytes amplify neuronal damage (201). A miscalculated interactive cascade of ROS, increased pro-inflammatory cytokine production, and downregulation of anti-inflammatory cytokines along with disrupted BBB play decisive roles in astrocyte functions (202-204). The third component of $\mathrm{BBB}$ is pericytes which have multifaceted roles in the brain following ischemic injury.

Brain injury causes increased expression of adhesion molecules (ICAM-1 and VCAM-1) on pericytes in response to inflammatory cytokines $(205,206)$. In addition to this, various other molecules are overly expressed on pericytes including $\alpha$ smooth muscle actin, Platelet-derived growth factor subunit B (PDGF- $\beta$ ), transforming growth factor- $\beta$ (TGF- $\beta$ ), and andangiopoieten-1 (207-210). Pericytes have a constructive function against inflammatory responses, of these some include contractile maneuvers with endothelial smooth muscles, immune and phagocytic roles, migration to endothelial cells to

\section{REFERENCES}

1. MEMBERS WG, Roger VL, Go AS, Lloyd-Jones DM, Benjamin EJ, Berry JD, et al. Heart Disease and Stroke Statistics-2012 Update: A Report From the American Heart Association. Circulation (2012) 125(1):e2. doi: 10.1161/ CIR.0b013e31823ac046

2. Grysiewicz RA, Thomas K, Pandey DK. Epidemiology of Ischemic and Hemorrhagic Stroke: Incidence, Prevalence, Mortality, and Risk Factors. Neurol Clinics (2008) 26(4):871-95. doi: 10.1016/j.ncl.2008.07.003

3. Goldstein L, Amarenco P, Szarek M, Callahan AR, Hennerici M, Sillesen H, et al. Hemorrhagic Stroke in the Stroke Prevention by Aggressive Reduction provide supportive functions, angiogenic support, and stem cell functions (211-216). However, once the BBB losses integrity as a result of neuroinflammatory chain reaction, these supportive and angiogenic functions of astrocytes are compromised severely (217). The fourth component of the BBB, i.e., microglial cells, has been elaborated on above.

\section{CONCLUSIONS}

Non-availability of clinically reliable therapeutic interventions for limiting stroke-related morbidities and mortalities puts the significance of clinical trials into question. This suggests that such efforts are not specifically targeted enough or that the targeted mechanisms differed between species, as most of the mechanistic studies are carried out in small animal models of stroke. Contemporary trends in stroke studies are heading towards unearthing intricate intracellular signaling pathways which are involved in neuroinflammation and stroke damage. Establishing a significant link between these pathways can only help explore potential targets for finding therapeutic interventions. The neuroinflammatory triangle entails diverse links which are central to stroke-related damage. Further reconnoitering this neuroinflammatory triangle might be rewarding and aid in finding and clinically translating novel therapeutic targets.

\section{AUTHOR CONTRIBUTIONS}

MK planned the study and undertook critical scrutiny of the manuscript to highlight and remove discrepancies or conflict of concepts. ZS wrote the manuscript. CA undertook review with particular focus on removing technical mistakes. AZ undertook multiple reviews to give shape to the final draft of the manuscript. DH critically reviewed the manuscript and provided input. SM contributed to manuscript writing and critically reviewed. All authors contributed to the article and approved the submitted version.

\section{ACKNOWLEDGMENTS}

We are thankful to Prof. Dr. Med. Markus Schwaninger (Universität zu Lübeck, Germany) for his reading of the manuscript and for giving valuable suggestions for subsequent correction.

in Cholesterol Levels Study. Neurology (2008) 70(24 Part 2):2364-70. doi: 10.1212/01.wnl.0000296277.63350.77

4. Powers WJ, Derdeyn CP, Biller J, Coffey CS, Hoh BL, Edward C, et al. Acute Ischemic Stroke Endovascular Therapy. Stroke (2015) p:0000000000000074. doi: 10.1161/STR.0000000000000074

5. Sims NR, Anderson MF. Mitochondrial Contributions to Tissue Damage in Stroke. Neurochem Int (2002) 40(6):511-26. doi: 10.1016/S0197-0186(01) 00122-X

6. Rodrigo R, Fernández-Gajardo R, Gutiérrez R, Manuel Matamala J, Carrasco R, Miranda-Merchak A, et al. Oxidative Stress and Pathophysiology of Ischemic Stroke: Novel Therapeutic Opportunities. CNS Neurol Disorders Drug Targets 
(Formerly Curr Drug Targets CNS Neurol Disorders) (2013) 12(5):698-714. doi: 10.2174/1871527311312050015

7. Lambertsen KL, Biber K, Finsen B. Inflammatory Cytokines in Experimental and Human Stroke. J Cereb Blood Flow Metab (2012) 32(9):1677-98. doi: $10.1038 / \mathrm{jcbfm} .2012 .88$

8. Yang Y, Rosenberg GA. Blood-brain Barrier Breakdown in Acute and Chronic Cerebrovascular Disease. Stroke (2011) 42(11):3323-8. doi: 10.1161/STROKEAHA.110.608257

9. Khatri R, McKinney AM, Swenson B, Janardhan V. Blood-brain Barrier, Reperfusion Injury, and Hemorrhagic Transformation in Acute Ischemic Stroke. Neurology (2012) 79(13 Supplement 1):S52-7. doi: 10.1212/ WNL.0b013e3182697e70

10. Liesz A, Zhou W, Mracskó É, Karcher S, Bauer H, Schwarting S, et al. Inhibition of Lymphocyte Trafficking Shields the Brain Against Deleterious Neuroinflammation After Stroke. Brain (2011) 134(3):704-20. doi: 10.1093/brain/awr008

11. Liesz A, Zhou W, Na S-Y, Hämmerling GJ, Garbi N, Karcher S, et al. Boosting Regulatory T Cells Limits Neuroinflammation in Permanent Cortical Stroke. J Neurosci (2013) 33(44):17350-62. doi: 10.1523/JNEUROSCI.4901-12.2013

12. Rao JS, Kellom M, Kim HW, Rapoport SI, Reese EA. Neuroinflammation and Synaptic Loss. Neurochem Res (2012) 37(5):903-10. doi: 10.1007/ s11064-012-0708-2

13. McColl B, Allan S, Rothwell N. Systemic Infection, Inflammation and Acute Ischemic Stroke. Neuroscience (2009) 158(3):1049-61. doi: 10.1016/ j.neuroscience.2008.08.019

14. Chamorro Á, Meisel A, Planas AM, Urra X, Van De Beek D, Veltkamp R. The Immunology of Acute Stroke. Nat Rev Neurol (2012) 8(7):401. doi: 10.1038/nrneurol.2012.98

15. Tobin MK, Bonds JA, Minshall RD, Pelligrino DA, Testai FD, Lazarov O. Neurogenesis and Inflammation After Ischemic Stroke: What Is Known and Where We Go From Here. J Cereb Blood Flow Metab (2014) 34(10):1573-84. doi: $10.1038 / j \mathrm{cbfm} .2014 .130$

16. Jin R, Yang G, Li G. Inflammatory Mechanisms in Ischemic Stroke: Role of Inflammatory Cells. J Leukocyte Biol (2010) 87(5):779-89. doi: 10.1189/jlb.1109766

17. Tremblay M-Ė, Stevens B, Sierra A, Wake H, Bessis A, Nimmerjahn A. The Role of Microglia in the Healthy Brain. J Neurosci (2011) 31(45):16064-9. doi: 10.1523/JNEUROSCI.4158-11.2011

18. Nimmerjahn A, Kirchhoff F, Helmchen F. Resting Microglial Cells Are Highly Dynamic Surveillants of Brain Parenchyma In Vivo. Science (2005) 308(5726):1314-8. doi: 10.1126/science.1110647

19. Benveniste EN. Inflammatory Cytokines Within the Central Nervous System: Sources, Function, and Mechanism of Action. Am J Physiol Cell Physiol (1992) 263(1):C1-C16. doi: 10.1152/ajpcell.1992.263.1.C1

20. Napoli I, Neumann H. Protective Effects of Microglia in Multiple Sclerosis. Exp Neurol (2010) 225(1):24-8. doi: 10.1016/j.expneurol.2009.04.024

21. Akiyama H, Arai T, Kondo H, Tanno E, Haga C, Ikeda K. Cell Mediators of Inflammation in the Alzheimer Disease Brain. Alzheimer Dis Assoc Disord (2000) 14(1):S47-53. doi: 10.1097/00002093-200000001-00008

22. Yenari MA, Kauppinen TM, Swanson RA. Microglial Activation in Stroke: Therapeutic Targets. Neurotherapeutics (2010) 7(4):378-91. doi: 10.1016/ j.nurt.2010.07.005

23. Hughes V. Microglia: The Constant Gardeners. Nat News (2012) 485 (7400):570. doi: 10.1038/485570a

24. Hu X, Li P, Guo Y, Wang H, Leak RK, Chen S, et al. Microglia/macrophage Polarization Dynamics Reveal Novel Mechanism of Injury Expansion After Focal Cerebral Ischemia. Stroke (2012) 43(11):3063-70. doi: 10.1161/ STROKEAHA.112.659656

25. Hu X, Leak RK, Shi Y, Suenaga J, Gao Y, Zheng P, et al. Microglial and Macrophage Polarization-New Prospects for Brain Repair. Nat Rev Neurol (2015) 11(1):56. doi: 10.1038/nrneurol.2014.207

26. Taylor RA, Sansing LH. Microglial Responses After Ischemic Stroke and Intracerebral Hemorrhage. Clin Dev Immunol (2013) 2013:746068. doi: $10.1155 / 2013 / 746068$

27. Ma Y, Wang J, Wang Y, Yang G-Y. The Biphasic Function of Microglia in Ischemic Stroke. Prog Neurobiol (2017) 157:247-72. doi: 10.1016/j.pneurobio. 2016.01.005

28. Ekdahl C, Kokaia Z, Lindvall O. Brain Inflammation and Adult Neurogenesis: The Dual Role of Microglia. Neuroscience (2009) 158(3):1021-9. doi: 10.1016/ j.neuroscience.2008.06.052
29. Sriram K, O'Callaghan JP. Divergent Roles for Tumor Necrosis Factor- $\alpha$ in the Brain. J Neuroimmune Pharmacol (2007) 2(2):140-53. doi: 10.1007/ s11481-007-9070-6

30. Doyle KP, Simon RP, Stenzel-Poore MP. Mechanisms of Ischemic Brain Damage. Neuropharmacology (2008) 55(3):310-8. doi: 10.1016/ j.neuropharm.2008.01.005

31. Marsh BJ, Williams-Karnesky RL, Stenzel-Poore MP. Toll-Like Receptor Signaling in Endogenous Neuroprotection and Stroke. Neuroscience (2009) 158(3):1007-20. doi: 10.1016/j.neuroscience.2008.07.067

32. Jin R, Liu L, Zhang S, Nanda A, Li G. Role of Inflammation and Its Mediators in Acute Ischemic Stroke. J Cardiovasc Trans Res (2013) 6(5):834-51. doi 10.1007/s12265-013-9508-6

33. Alexander JJ, Jacob A, Cunningham P, Hensley L, Quigg RJ. TNF is a Key Mediator of Septic Encephalopathy Acting Through Its Receptor, TNF Receptor-1. Neurochem Int (2008) 52(3):447-56. doi: 10.1016/j.neuint.2007.08.006

34. He S, Wang L, Miao L, Wang T, Du F, Zhao L, et al. Receptor Interacting Protein Kinase-3 Determines Cellular Necrotic Response to TNF- $\alpha$. Cell (2009) 137(6):1100-11. doi: 10.1016/j.cell.2009.05.021

35. Szlosarek P, Charles KA, Balkwill FR. Tumour Necrosis Factor- $\alpha$ as a Tumour Promoter. Eur J Cancer (2006) 42(6):745-50. doi: 10.1016/ j.ejca.2006.01.012

36. Ho CC-Y, Rideout HJ, Ribe E, Troy CM, Dauer WT. The Parkinson Disease Protein Leucine-Rich Repeat Kinase 2 Transduces Death Signals via FasAssociated Protein With Death Domain and Caspase-8 in a Cellular Model of Neurodegeneration. J Neurosci (2009) 29(4):1011-6. doi: 10.1523/ JNEUROSCI.5175-08.2009

37. Zhang D, Lin J, Han J. Receptor-Interacting Protein (RIP) Kinase Family. Cell Mol Immunol (2010) 7(4):243. doi: 10.1038/cmi.2010.10

38. Bogoyevitch MA, Ngoei KR, Zhao TT, Yeap YY, Ng DC. C-Jun N-Terminal Kinase (JNK) Signaling: Recent Advances and Challenges. Biochim Biophys Acta (BBA) Proteins Proteomics (2010) 1804(3):463-75. doi: 10.1016/ j.bbapap.2009.11.002

39. Liu T, Clark R, McDonnell P, Young P, White R, Barone F, et al. Tumor Necrosis Factor-Alpha Expression in Ischemic Neurons. Stroke (1994) 25 (7):1481-8. doi: 10.1161/01.STR.25.7.1481

40. Perera MN, Ma HK, Arakawa S, Howells DW, Markus R, Rowe CC, et al. Inflammation Following Stroke. J Clin Neurosci (2006) 13(1):1-8. doi: 10.1016/j.jocn.2005.07.005

41. Denes A, Pinteaux E, Rothwell NJ, Allan SM. Interleukin-1 and Stroke: Biomarker, Harbinger of Damage, and Therapeutic Target. Cerebrovascular Dis (2011) 32(6):517-27. doi: 10.1159/000332205

42. Allan SM, Tyrrell PJ, Rothwell NJ. Interleukin-1 and Neuronal Injury. Nat Rev Immunol (2005) 5(8):629. doi: 10.1038/nril664

43. Rahman M, Muhammad S, Khan MA, Chen H, Ridder DA, Müller-Fielitz H, et al. The $\beta$-Hydroxybutyrate Receptor HCA 2 Activates a Neuroprotective Subset of Macrophages. Nat Commun (2014) 5(1):1-11. doi: 10.1038/ ncomms 4944

44. Spulber S, Bartfai T, Schultzberg M. IL-1/IL-1ra Balance in the Brain Revisited-Evidence From Transgenic Mouse Models. Brain Behav Immun (2009) 23(5):573-9. doi: 10.1016/j.bbi.2009.02.015

45. McCandless EE, Budde M, Lees JR, Dorsey D, Lyng E, Klein RS. IL-1R Signaling Within the Central Nervous System Regulates CXCL12 Expression at the Blood-Brain Barrier and Disease Severity During Experimental Autoimmune Encephalomyelitis. J Immunol (2009) 183(1):613-20. doi: 10.4049/jimmunol.0802258

46. Craft JM, Watterson DM, Hirsch E, Van Eldik LJ. Interleukin 1 Receptor Antagonist Knockout Mice Show Enhanced Microglial Activation and Neuronal Damage Induced by Intracerebroventricular Infusion of Human B-Amyloid. J Neuroinflamm (2005) 2(1):15. doi: 10.1186/1742-2094-2-15

47. Weber A, Wasiliew P, Kracht M. Interleukin-1 (IL-1) Pathway. Sci Signal (2010) 3(105):cm1-1. doi: 10.1126/scisignal.3105 cm1

48. Maroso M, Balosso S, Ravizza T, Liu J, Bianchi M, Vezzani A. Interleukin-1 Type 1 Receptor/Toll-Like Receptor Signalling in Epilepsy: The Importance of IL-1beta and High-Mobility Group Box 1. J Internal Med (2011) 270 (4):319-26. doi: 10.1111/j.1365-2796.2011.02431.x

49. Ahn KS, AGGARWAL BB. Transcription Factor NF-kb: A Sensor for Smoke and Stress Signals. Ann New York Acad Sci (2005) 1056(1):218-33. doi: $10.1196 /$ annals. 1352.026 
50. Kaminska B. MAPK Signalling Pathways as Molecular Targets for AntiInflammatory Therapy-From Molecular Mechanisms to Therapeutic Benefits. Biochim Biophys Acta (BBA) Proteins Proteomics (2005) 1754(12):253-62. doi: 10.1016/j.bbapap.2005.08.017

51. Ridder D, Schwaninger M. NF- $\kappa b$ Signaling in Cerebral Ischemia. Neuroscience (2009) 158(3):995-1006. doi: 10.1016/j.neuroscience.2008.07.007

52. Schwaninger $\mathrm{M}$, Inta I, Herrmann O. NF- $\kappa b$ Signalling in Cerebral Ischaemia. United Kingdom, London: Portland Press Ltd (2006).

53. Raza S, Khan M, Ahmad A, Ashafaq M, Islam F, Wagner A, et al. Neuroprotective Effect of Naringenin Is Mediated Through Suppression of NF-кb Signaling Pathway in Experimental Stroke. Neuroscience (2013) 230:157-71. doi: 10.1016/j.neuroscience.2012.10.041

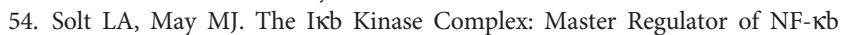
Signaling. Immunol Res (2008) 42(1-3):3. doi: 10.1007/s12026-008-8025-1

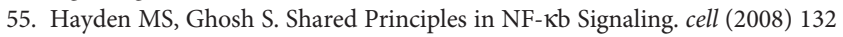
(3):344-62. doi: 10.1016/j.cell.2008.01.020

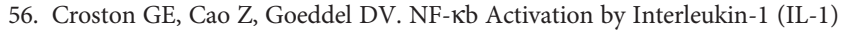
Requires an IL-1 Receptor-Associated Protein Kinase Activity. J Biol Chem (1995) 270(28):16514-7. doi: 10.1074/jbc.270.28.16514

57. Tak PP, Firestein GS. NF- $\mathrm{kb}$ : A Key Role in Inflammatory Diseases. J Clin Invest (2001) 107(1):7-11. doi: 10.1172/JCI11830

58. Weston CR, Davis RJ. The JNK Signal Transduction Pathway. Curr Opin Cell Biol (2007) 19(2):142-9. doi: 10.1016/j.ceb.2007.02.001

59. Lin A. Activation of the JNK Signaling Pathway: Breaking the Brake on Apoptosis. Bioessays (2003) 25(1):17-24. doi: 10.1002/bies.10204

60. Dong Y, Liu HD, Zhao R, Yang CZ, Chen XQ, Wang XH, et al. Ischemia Activates JNK/c-Jun/AP-1 Pathway to Up-Regulate 14-3-3 $\gamma$ in Astrocyte. J Neurochem (2009) 109:182-8. doi: 10.1111/j.1471-4159.2009.05974.x

61. Nijboer CH, van der Kooij MA, van Bel F, Ohl F, Heijnen CJ, Kavelaars A. Inhibition of the JNK/AP-1 Pathway Reduces Neuronal Death and Improves Behavioral Outcome After Neonatal Hypoxic-Ischemic Brain Injury. Brain Behav Immun (2010) 24(5):812-21. doi: 10.1016/j.bbi.2009.09.008

62. Raivich G, Behrens A. Role of the AP-1 Transcription Factor C-Jun in Developing, Adult and Injured Brain. Prog Neurobiol (2006) 78(6):347-63. doi: 10.1016/j.pneurobio.2006.03.006

63. Choudhury GR, Ryou M-G, Poteet E, Wen Y, He R, Sun F, et al. Involvement of P38 MAPK in Reactive Astrogliosis Induced by Ischemic Stroke. Brain Res (2014) 1551:45-58. doi: 10.1016/j.brainres.2014.01.013

64. Sun J, Nan G. The Mitogen-Activated Protein Kinase (MAPK) Signaling Pathway as a Discovery Target in Stroke. J Mol Neurosci (2016) 59(1):90-8. doi: 10.1007/s12031-016-0717-8

65. Yang I, Han SJ, Kaur G, Crane C, Parsa AT. The Role of Microglia in Central Nervous System Immunity and Glioma Immunology. J Clin Neurosci (2010) 17(1):6-10. doi: 10.1016/j.jocn.2009.05.006

66. Jin R, Yang G, Li G. Molecular Insights and Therapeutic Targets for BloodBrain Barrier Disruption in Ischemic Stroke: Critical Role of Matrix Metalloproteinases and Tissue-Type Plasminogen Activator. Neurobiol Dis (2010) 38(3):376-85. doi: 10.1016/j.nbd.2010.03.008

67. Ren X, Akiyoshi AA, Vandenbark PD, Hurn H, Offner H. CD4+ FoxP3+ Regulatory T-Cells in Cerebral Ischemic Stroke. Metab Brain Dis (2011) 26 (1):87-90. doi: 10.1007/s11011-010-9226-6

68. O'Connor RA, Prendergast CT, Sabatos CA, Lau CW, Leech MD, Wraith DC, et al. Cutting Edge: Th1 Cells Facilitate the Entry of Th17 Cells to the Central Nervous System During Experimental Autoimmune Encephalomyelitis. J Immunol (2008) 181(6):3750-4. doi: 10.4049/ jimmunol.181.6.3750

69. Muhammad S, Barakat W, Stoyanov S, Murikinati S, Yang H, Tracey KJ, et al. The HMGB1 Receptor RAGE Mediates Ischemic Brain Damage. J Neurosci (2008) 28(46):12023-31. doi: 10.1523/JNEUROSCI.2435-08.2008

70. Young H, Bream J. IFN- $\gamma$ : Recent Advances in Understanding Regulation of Expression, Biological Functions, and Clinical Applications. In: Interferon: The 50th Anniversary. United Kingdom, London: Springer (2007). p. 97-117.

71. Wensky AK, Furtado GC, Marcondes MCG, Chen S, Manfra D, Lira SA, et al. IFN- $\gamma$ Determines Distinct Clinical Outcomes in Autoimmune Encephalomyelitis. J Immunol (2005) 174(3):1416-23. doi: 10.4049/ jimmunol.174.3.1416

72. Lykens JE, Terrell CE, Zoller EE, Divanovic S, Trompette A, Karp CL, et al. Mice With a Selective Impairment of IFN- $\gamma$ Signaling in Macrophage
Lineage Cells Demonstrate the Critical Role of IFN- $\gamma$-Activated Macrophages for the Control of Protozoan Parasitic Infections In Vivo. J Immunol (2010) 184(2):877-85. doi: 10.4049/jimmunol.0902346

73. Haeusler KG, Schmidt WU, Foehring F, Meisel C, Guenther C, Brunecker P, et al. Immune Responses After Acute Ischemic Stroke or Myocardial Infarction. Int J Cardiol (2012) 155(3):372-7. doi: 10.1016/j.ijcard. 2010.10.053

74. Butovsky O, Bukshpan S, Kunis G, Jung S, Schwartz M. Microglia can be Induced by IFN- $\gamma$ or IL- 4 to Express Neural or Dendritic-Like Markers. Mol Cell Neurosci (2007) 35(3):490-500. doi: 10.1016/j.mcn.2007.04.009

75. Wang R, Jaw JJ, Stutzman NC, Zou Z, Sun PD. Natural Killer Cell-Produced IFN- $\gamma$ and TNF- $\alpha$ Induce Target Cell Cytolysis Through Up-Regulation of ICAM-1. J Leukocyte Biol (2012) 91(2):299-309. doi: 10.1189/jlb.0611308

76. Zaremba J, Ilkowski J, Losy J. Serial Measurements of Levels of the Chemokines CCL2, CCL3 and CCL5 in Serum of Patients With Acute Ischaemic Stroke. Folia Neuropathol (2006) 44(4):282.

77. Amin M, Vakilian A, Mahmoodi MH, Hassanshahi G, Falahati-pour SK, Dolatabadi MR, et al. Circulatory Levels of Cxc Motif Chemokine Ligands 1, 9, and 10 Are Elevated in Patients With Ischemic Stroke. Eurasian J Med (2017) 49(2):92. doi: 10.5152/eurasianjmed.2017.17022

78. Theodorou G, Marousi S, Ellul J, Mougiou A, Theodori E, Mouzaki A, et al. T Helper 1 (Th1)/Th2 Cytokine Expression Shift of Peripheral Blood CD4+ and CD8+ T Cells in Patients at the Post-Acute Phase of Stroke. Clin Exp Immunol (2008) 152(3):456-63. doi: 10.1111/j.1365-2249.2008.03650.x

79. Offner H, Vandenbark A, Hurn PD. Effect of Experimental Stroke on Peripheral Immunity: CNS Ischemia Induces Profound Immunosuppression. Neuroscience (2009) 158(3):1098-111. doi: 10.1016/j.neuroscience.2008.05.033

80. Thöne J, Ellrichmann G, Seubert S, Peruga I, Lee D-H, Conrad R, et al. Modulation of Autoimmune Demyelination by Laquinimod via Induction of Brain-Derived Neurotrophic Factor. Am J Pathol (2012) 180(1):267-74. doi: 10.1016/j.ajpath.2011.09.037

81. Takefuji S, Murase T, Sugimura Y, Takagishi Y, Hayasaka S, Oiso Y, et al. Role of Microglia in the Pathogenesis of Osmotic-Induced Demyelination. Exp Neurol (2007) 204(1):88-94. doi: 10.1016/j.expneurol.2006.09.025

82. Oishi S, Takano R, Tamura S, Tani S, Iwaizumi M, Hamaya Y, et al. M2 Polarization of Murine Peritoneal Macrophages Induces Regulatory Cytokine Production and Suppresses T-Cell Proliferation. Immunology (2016) 149(3):320-8. doi: 10.1111/imm.12647

83. Zhang M, Downes CE, Wong CH, Brody KM, Guio-Agulair PL, Gould J, et al. Type-I Interferon Signalling Through IFNAR1 Plays a Deleterious Role in the Outcome After Stroke. Neurochem Int (2017) 108:472-80. doi: 10.1016/j.neuint.2017.06.009

84. Taylor JM, Moore Z, Minter MR, Crack PJ. Type-I Interferon Pathway in Neuroinflammation and Neurodegeneration: Focus on Alzheimer's Disease. J Neural Transm (2018) 125(5):797-807. doi: 10.1007/s00702-017-1745-4

85. De Weerd NA, Nguyen T. The Interferons and Their ReceptorsDistribution and Regulation. Immunol Cell Biol (2012) 90(5):483-91. doi: 10.1038/icb.2012.9

86. Zurney J, Howard KE, Sherry B. Basal Expression Levels of IFNAR and JakSTAT Components Are Determinants of Cell-Type-Specific Differences in Cardiac Antiviral Responses. J Virol (2007) 81(24):13668-80. doi: 10.1128/ JVI.01172-07

87. Zaidi MR, Merlino G. The Two Faces of Interferon- $\gamma$ in Cancer. Clin Cancer Res (2011) 17(19):6118-24. doi: 10.1158/1078-0432.CCR-11-0482

88. O'Shea JJ, Kontzias A, Yamaoka K, Tanaka Y, Laurence A. Janus Kinase Inhibitors in Autoimmune Diseases. Ann Rheum Dis (2013) 72(suppl 2): ii111-5. doi: 10.1136/annrheumdis-2012-202576

89. Moran LB, Duke DC, Graeber MB. The Microglial Gene Regulatory Network Activated by Interferon-Gamma. J Neuroimmunol (2007) 183(12):1-6. doi: 10.1016/j.jneuroim.2006.10.023

90. Schmitt MJ, Philippidou D, Reinsbach SE, Margue C, WieneckeBaldacchino A, Nashan D, et al. Interferon- $\gamma$-Induced Activation of Signal Transducer and Activator of Transcription 1 (STAT1) Up-Regulates the Tumor Suppressing microRNA-29 Family in Melanoma Cells. Cell Commun Signal (2012) 10(1):41. doi: 10.1186/1478-811X-10-41

91. Luu K, Greenhill CJ, Majoros A, Decker T, Jenkins BJ, Mansell A. STAT1 Plays a Role in TLR Signal Transduction and Inflammatory Responses. Immunol Cell Biol (2014) 92(9):761-9. doi: 10.1038/icb.2014.51 
92. Chen H-Z, Guo S, Li Z-Z, Lu Y, Jiang D-S, Zhang R, et al. A Critical Role for Interferon Regulatory Factor 9 in Cerebral Ischemic Stroke. J Neurosci (2014) 34(36):11897-912. doi: 10.1523/JNEUROSCI.1545-14.2014

93. Baron R, Nemirovsky A, Harpaz I, Cohen H, Owens T, Monsonego A. IFN- $\gamma$ Enhances Neurogenesis in Wild-Type Mice and in a Mouse Model of Alzheimer's Disease. FASEB J (2008) 22(8):2843-52. doi: 10.1096/fj.08-105866

94. Hagberg H, Mallard C, Jacobsson B. Role of Cytokines in Preterm Labour and Brain Injury. BJOG: Int J Obstet Gynaecol (2005) 112:16-8. doi: 10.1111/ j.1471-0528.2005.00578.x

95. Waje-Andreassen U, Kråkenes J, Ulvestad E, Thomassen L, Myhr KM, Aarseth J, et al. IL-6: An Early Marker for Outcome in Acute Ischemic Stroke. Acta Neurol Scand (2005) 111(6):360-5. doi: 10.1111/j.16000404.2005.00416.x

96. Klehmet J, Harms JH, Richter M, Prass K, Volk H, Dirnagl U, et al. StrokeInduced Immunodepression and Post-Stroke Infections: Lessons From the Preventive Antibacterial Therapy in Stroke Trial. Neuroscience (2009) 158 (3):1184-93. doi: 10.1016/j.neuroscience.2008.07.044

97. Hang C-H, Shi J-X, Li J-S, Li W-Q, Wu W. Expressions of Intestinal NF- $\mathrm{kb}$, TNF- $\alpha$, and IL-6 Following Traumatic Brain Injury in Rats. J Surg Res (2005) 123(2):188-93. doi: 10.1016/j.jss.2004.08.002

98. Huang N-L, Chiang S-H, Hsueh C-H, Liang Y-J, Chen Y-J, Lai L-P. Metformin Inhibits TNF- $\alpha$-Induced I $\kappa b$ Kinase Phosphorylation, I $\kappa b-\alpha$ Degradation and IL-6 Production in Endothelial Cells Through PI3KDependent AMPK Phosphorylation. Int J Cardiol (2009) 134(2):169-75. doi: 10.1016/j.ijcard.2008.04.010

99. Amantea D, Nappi G, Bernardi G, Bagetta G, Corasaniti MT. Post-Ischemic Brain Damage: Pathophysiology and Role of Inflammatory Mediators. FEBS J (2009) 276(1):13-26. doi: 10.1111/j.1742-4658.2008.06766.x

100. Rodríguez-Yáñez M, Castillo J. Role of Inflammatory Markers in Brain Ischemia. Curr Opin Neurol (2008) 21(3):353-7. doi: 10.1097/WCO. Ob013e3282ffafbf

101. Guo Y, Xu F, Lu T, Duan Z, Zhang Z. Interleukin-6 Signaling Pathway in Targeted Therapy for Cancer. Cancer Treat Rev (2012) 38(7):904-10. doi: 10.1016/j.ctrv.2012.04.007

102. Tanaka T, Narazaki M, Kishimoto T. IL-6 in Inflammation, Immunity, and Disease. Cold Spring Harbor Perspect Biol (2014) 6(10):a016295. doi: 10.1101/cshperspect.a016295

103. Linker RA, Lühder F, Kallen K-J, Lee D-H, Engelhardt B, Rose-John S, et al. IL-6 Transsignalling Modulates the Early Effector Phase of EAE and Targets the Blood-Brain Barrier. J Neuroimmunol (2008) 205(1-2):64-72. doi: 10.1016/j.jneuroim.2008.09.007

104. Schafer ZT, Brugge JS. IL-6 Involvement in Epithelial Cancers. J Clin Invest (2007) 117(12):3660-3. doi: 10.1172/JCI34237

105. Barnes TC, Anderson ME, Moots RJ. The Many Faces of Interleukin-6: The Role of IL-6 in Inflammation, Vasculopathy, and Fibrosis in Systemic Sclerosis. Int J Rheumatol (2011) 2011:21608. doi: 10.1155/2011/721608

106. Kang SS, Keasey MP, Arnold SA, Reid R, Geralds J, Hagg T. Endogenous CNTF Mediates Stroke-Induced Adult CNS Neurogenesis in Mice. Neurobiol Dis (2013) 49:68-78. doi: 10.1016/j.nbd.2012.08.020

107. Garbers C, Aparicio-Siegmund S, Rose-John S. The IL-6/Gp130/STAT3 Signaling Axis: Recent Advances Towards Specific Inhibition. Curr Opin Immunol (2015) 34:75-82. doi: 10.1016/j.coi.2015.02.008

108. Morieri ML, Passaro A, Zuliani G. Interleukin-6 "Trans-Signaling" and Ischemic Vascular Disease: The Important Role of Soluble Gp130. Mediators Inflamm (2017) 2017. doi: 10.1155/2017/1396398

109. Ebihara N, Matsuda A, Nakamura S, Matsuda H, Murakami A. Role of the IL-6 Classic-and Trans-Signaling Pathways in Corneal Sterile Inflammation and Wound Healing. Invest Ophthalmol Visual Sci (2011) 52(12):8549-57. doi: $10.1167 /$ iovs.11-7956

110. Scheller J, Grötzinger J, Rose-John S. Updating Interleukin-6 Classic-and Trans-Signaling. Signal Transduct (2006) 6(4):240-59. doi: 10.1002/ sita.200600086

111. Mitsuyama K, Sata M, Rose-John S. Interleukin-6 Trans-Signaling in Inflammatory Bowel Disease. Cytokine Growth Factor Rev (2006) 17 (6):451-61. doi: 10.1016/j.cytogfr.2006.09.003

112. Rose-John S, Waetzig GH, Scheller J, Grötzinger J, Seegert D. The IL-6/sIL6R Complex as a Novel Target for Therapeutic Approaches. Expert Opin Ther Targets (2007) 11(5):613-24. doi: 10.1517/14728222.11.5.613
113. Tron K, Samoylenko A, Musikowski G, Kobe F, Immenschuh S, Schaper F, et al. Regulation of Rat Heme Oxygenase-1 Expression by Interleukin-6 via the Jak/STAT Pathway in Hepatocytes. J Hepatol (2006) 45(1):72-80. doi: 10.1016/j.jhep.2005.12.019

114. Frebel K, Wiese S. Signalling Molecules Essential for Neuronal Survival and Differentiation. United Kingdom, London: Portland Press Limited (2006).

115. Scheller J, Chalaris A, Schmidt-Arras D, Rose-John S. The Pro-and AntiInflammatory Properties of the Cytokine Interleukin-6. Biochim Biophys Acta (BBA) Molecular Cell Res (2011) 1813(5):878-88. doi: 10.1016/ j.bbamcr.2011.01.034

116. Loeffler S, Fayard B, Weis J, Weissenberger J. Interleukin-6 Induces Transcriptional Activation of Vascular Endothelial Growth Factor (VEGF) in Astrocytes In Vivo and Regulates VEGF Promoter Activity in Glioblastoma Cells via Direct Interaction Between STAT3 and Sp1. Int J Cancer (2005) 115(2):202-13. doi: 10.1002/ijc.20871

117. Alexandrova ML, Bochev PG. Oxidative Stress During the Chronic Phase After Stroke. Free Radical Biol Med (2005) 39(3):297-316. doi: 10.1016/ j.freeradbiomed.2005.04.017

118. Wang Q, Tang XN, Yenari MA. The Inflammatory Response in Stroke. J Neuroimmunol (2007) 184(1-2):53-68. doi: 10.1016/j.jneuroim.2006.11.014

119. D'Autréaux B, Toledano MB. ROS as Signalling Molecules: Mechanisms That Generate Specificity in ROS Homeostasis. Nat Rev Mol Cell Biol (2007) 8(10):813-24. doi: 10.1038/nrm2256

120. Hamanaka RB, Chandel NS. Mitochondrial Reactive Oxygen Species Regulate Cellular Signaling and Dictate Biological Outcomes. Trends Biochem Sci (2010) 35(9):505-13. doi: 10.1016/j.tibs.2010.04.002

121. Kohchi $\mathrm{C}$, Inagawa $\mathrm{H}$, Nishizawa $\mathrm{T}$, Soma G-I. ROS and Innate Immunity. Anticancer Res (2009) 29(3):817-21.

122. Niizuma K, Yoshioka H, Chen H, Kim GS, Jung JE, Katsu M, et al. Mitochondrial and Apoptotic Neuronal Death Signaling Pathways in Cerebral Ischemia. Biochim Biophys Acta (BBA) Molecular Basis Dis (2010) 1802(1):92-9. doi: 10.1016/j.bbadis.2009.09.002

123. Allen CL, Bayraktutan U. Oxidative Stress and Its Role in the Pathogenesis of Ischaemic Stroke. Int J Stroke (2009) 4(6):461-70. doi: 10.1111/j.17474949.2009.00387.x

124. Okayama Y. Oxidative Stress in Allergic and Inflammatory Skin Diseases. Curr Drug Targets Inflamm Allergy (2005) 4(4):517-9. doi: 10.2174/ 1568010054526386

125. Nencini C, Giorgi G, Micheli L. Protective Effect of Silymarin on Oxidative Stress in Rat Brain. Phytomedicine (2007) 14(2-3):129-35. doi: 10.1016/ j.phymed.2006.02.005

126. Aksenov M, Aksenova M, Butterfield D, Geddes J, Markesbery W. Protein Oxidation in the Brain in Alzheimer's Disease. Neuroscience (2001) 103 (2):373-83. doi: 10.1016/S0306-4522(00)00580-7

127. Mariani E, Polidori M, Cherubini A, Mecocci P. Oxidative Stress in Brain Aging, Neurodegenerative and Vascular Diseases: An Overview. J Chromatogr B (2005) 827(1):65-75. doi: 10.1016/j.jchromb.2005.04.023

128. Gilgun-Sherki Y, Melamed E, Offen D. Oxidative Stress InducedNeurodegenerative Diseases: The Need for Antioxidants That Penetrate the Blood Brain Barrier. Neuropharmacology (2001) 40(8):959-75. doi: 10.1016/S0028-3908(01)00019-3

129. Moon J-K, Shibamoto T. Antioxidant Assays for Plant and Food Components. J Agric Food Chem (2009) 57(5):1655-66. doi: 10.1021/ jf803537k

130. Margaill I, Plotkine M, Lerouet D. Antioxidant Strategies in the Treatment of Stroke. Free Radical Biol Med (2005) 39(4):429-43. doi: 10.1016/ j.freeradbiomed.2005.05.003

131. Clark TA, Lee HP, Rolston RK, Zhu X, Marlatt MW, Castellani RJ, et al. Oxidative Stress and Its Implications for Future Treatments and Management of Alzheimer Disease. Int J Biomed Sci: IJBS (2010) 6(3):225.

132. Todorova V, Blokland A. Mitochondria and Synaptic Plasticity in the Mature and Aging Nervous System. Curr Neuropharmacol (2017) 15(1):166-73. doi: 10.2174/1570159X14666160414111821

133. Liu Y, Pan Q, Zhao Y, He C, Bi K, Chen Y, et al. MicroRNA-155 Regulates ROS Production, NO Generation, Apoptosis and Multiple Functions of Human Brain Microvessel Endothelial Cells Under Physiological and Pathological Conditions. J Cell Biochem (2015) 116(12):2870-81. doi: $10.1002 /$ jcb. 25234 
134. Popa-Wagner A, Mitran S, Sivanesan S, Chang E, Buga A-M. ROS and Brain Diseases: The Good, the Bad, and the Ugly. Oxid Med Cell Longevity (2013) 2013:963520. doi: 10.1155/2013/963520

135. Benhar M, Dalyot I, Engelberg D, Levitzki A. Enhanced ROS Production in Oncogenically Transformed Cells Potentiates C-Jun N-Terminal Kinase and P38 Mitogen-Activated Protein Kinase Activation and Sensitization to Genotoxic Stress. Mol Cell Biol (2001) 21(20):6913-26. doi: 10.1128/ MCB.21.20.6913-6926.2001

136. Arnoult D, Soares F, Tattoli I, Girardin SE. Mitochondria in Innate Immunity. EMBO Rep (2011) 12(9):901-10. doi: 10.1038/embor.2011.157

137. Svegliati S, Cancello R, Sambo P, Luchetti M, Paroncini P, Orlandini G, et al. Platelet-Derived Growth Factor and Reactive Oxygen Species (ROS) Regulate Ras Protein Levels in Primary Human Fibroblasts via ERK1/2 Amplification of Ros and Ras in Systemic Sclerosis Fibroblasts. J Biol Chem (2005) 280(43):36474-82. doi: 10.1074/jbc.M502851200

138. Liu B, Chen Y, Clair DKS. ROS and P53: A Versatile Partnership. Free Radical Biol Med (2008) 44(8):1529-35. doi: 10.1016/j.freeradbiomed.2008.01.011

139. Ye S-F, Wu Y-H, Hou Z-Q, Zhang Q-Q. ROS and NF- $\mathrm{kb}$ Are Involved in Upregulation of IL-8 in A549 Cells Exposed to Multi-Walled Carbon Nanotubes. Biochem Biophys Res Commun (2009) 379(2):643-8. doi: 10.1016/j.bbrc.2008.12.137

140. Huo Y, Qiu W-Y, Pan Q, Yao Y-F, Xing K, Lou MF. Reactive Oxygen Species (ROS) Are Essential Mediators in Epidermal Growth Factor (EGF)Stimulated Corneal Epithelial Cell Proliferation, Adhesion, Migration, and Wound Healing. Exp Eye Res (2009) 89(6):876-86. doi: 10.1016/ j.exer.2009.07.012

141. Chien C-T, Yu H-J, Lin T-B, Lai M-K, Hsu S-M. Substance P via NK1 Receptor Facilitates Hyperactive Bladder Afferent Signaling via Action of ROS. Am J Physiol Renal Physiol (2003) 284(4):F840-51. doi: 10.1152/ ajprenal.00187.2002

142. Minutoli L, Puzzolo D, Rinaldi M, Irrera N, Marini H, Arcoraci V, et al. ROSMediated NLRP3 Inflammasome Activation in Brain, Heart, Kidney, and Testis Ischemia/Reperfusion Injury. Oxid Med Cell Longevity (2016) 2016:2183026. doi: 10.1155/2016/2183026

143. Nakanishi H, Wu Z. Microglia-Aging: Roles of Microglial Lysosome-and Mitochondria-Derived Reactive Oxygen Species in Brain Aging. Behav Brain Res (2009) 201(1):1-7. doi: 10.1016/j.bbr.2009.02.001

144. Schmeisser S, Priebe S, Groth M, Monajembashi S, Hemmerich P, Guthke R, et al. Neuronal ROS Signaling Rather Than AMPK/sirtuin-Mediated Energy Sensing Links Dietary Restriction to Lifespan Extension. Mol Metab (2013) 2 (2):92-102. doi: 10.1016/j.molmet.2013.02.002

145. Rose CF, Verkhratsky A, Parpura V. Astrocyte Glutamine Synthetase: Pivotal in Health and Disease. United Kingdom, London: Portland Press Ltd (2013).

146. Wolff V, Schlagowski A-I, Rouyer O, Charles A-L, Singh F, Auger C, et al. Tetrahydrocannabinol Induces Brain Mitochondrial Respiratory Chain Dysfunction and Increases Oxidative Stress: A Potential Mechanism Involved in Cannabis-Related Stroke. BioMed Res Int (2015) 2015:323706. doi: $10.1155 / 2015 / 323706$

147. Wang Y, Walsh SW, Kay HH. Placental Tissue Levels of Nonesterified Polyunsaturated Fatty Acids in Normal and Preeclamptic Pregnancies. Hypertension Pregnancy (2005) 24(3):235-45. doi: 10.1080/106419 50500281118

148. Kim HK, Park SK, Zhou J-L, Taglialatela G, Chung K, Coggeshall RE, et al. Reactive Oxygen Species (ROS) Play an Important Role in a Rat Model of Neuropathic Pain. Pain (2004) 111(1-2):116-24. doi: 10.1016/ j.pain.2004.06.008

149. Suzuki N, Miller G, Morales J, Shulaev V, Torres MA, Mittler R. Respiratory Burst Oxidases: The Engines of ROS Signaling. Curr Opin Plant Biol (2011) 14(6):691-9. doi: 10.1016/j.pbi.2011.07.014

150. Zarkovic K. 4-Hydroxynonenal and Neurodegenerative Diseases. Mol aspects Med (2003) 24(4-5):293-303. doi: 10.1016/S0098-2997(03)00024-4

151. Candelario-Jalil E, Mhadu NH, Al-Dalain SM, Martínez G, León OS. Time Course of Oxidative Damage in Different Brain Regions Following Transient Cerebral Ischemia in Gerbils. Neurosci Res (2001) 41(3):233-41. doi: 10.1016/S0168-0102(01)00282-6

152. Adibhatla RM, Hatcher J, Dempsey R. Lipids and Lipidomics in Brain Injury and Diseases. AAPS J (2006) 8(2):E314-21. doi: 10.1007/BF02854902
153. Butterfield DA, Castegna A, Lauderback CM, Drake J. Evidence That Amyloid Beta-Peptide-Induced Lipid Peroxidation and Its Sequelae in Alzheimer's Disease Brain Contribute to Neuronal Death. Neurobiol Aging (2002) 23(5):655-64. doi: 10.1016/S0197-4580(01)00340-2

154. Zorov DB, Juhaszova M, Sollott SJ. Mitochondrial ROS-Induced ROS Release: An Update and Review. Biochim Biophys Acta (BBA) Bioenergetics (2006) 1757(5-6):509-17. doi: 10.1016/j.bbabio.2006.04.029

155. Pradeep H, Diya JB, Shashikumar S, Rajanikant GK. Oxidative StressAssassin Behind the Ischemic Stroke. Folia Neuropathol (2012) 50(3):21930. doi: $10.5114 /$ fn. 2012.30522

156. Gariballa S, Hutchin T, Sinclair A. Antioxidant Capacity After Acute Ischaemic Stroke. Qjm (2002) 95(10):685-90. doi: 10.1093/qjmed/95.10.685

157. Zhang W, Hayashi T, Sasaki C, Sato K, Nagano I, Manabe Y, et al. Attenuation of Oxidative DNA Damage With a Novel Antioxidant EPC-K1 in Rat Brain Neuronal Cells After Transient Middle Cerebral Artery Occlusion. Neurol Res (2001) 23(6):676-80. doi: 10.1179/016164101101199027

158. Kumar L, Kumar S, Agarwal S. To Find the Role of DNA Damage Marker 8Hydroxy 2-Deoxy Guanosine in Patients of Prostate Cancer, Benign Prostatic Hyperplasia and Its Association to Other Prognostic Factors of Prostate Cancer. J Integr Nephrol Androl (2017) 4(2):55. doi: 10.4103/ jina.jina_5_17

159. Hwang IK, Yoo K-Y, Kim DS, Jeong Y-K, Dai Kim J, Shin H-K, et al. Neuroprotective Effects of Grape Seed Extract on Neuronal Injury by Inhibiting DNA Damage in the Gerbil Hippocampus After Transient Forebrain Ischemia. Life Sci (2004) 75(16):1989-2001. doi: 10.1016/ j.lfs.2004.05.013

160. Cho H-J, Yoon I-S, Yoon HY, Koo H, Jin Y-J, Ko S-H, et al. Polyethylene Glycol-Conjugated Hyaluronic Acid-Ceramide Self-Assembled Nanoparticles for Targeted Delivery of Doxorubicin. Biomaterials (2012) 33(4):1190-200. doi: 10.1016/j.biomaterials.2011.10.064

161. Hernandes MS, Britto LRG, Real CC, Martins D, Lopes LR. Reactive Oxygen Species and the Structural Remodeling of the Visual System After Ocular Enucleation. Neuroscience (2010) 170(4):1249-60. doi: 10.1016/ j.neuroscience.2010.07.065

162. Shirley R, Ord EN, Work LM. Oxidative Stress and the Use of Antioxidants in Stroke. Antioxidants (2014) 3(3):472-501. doi: 10.3390/antiox3030472

163. Del Zoppo G. The Neurovascular Unit in the Setting of Stroke. J Internal Med (2010) 267(2):156-71. doi: 10.1111/j.1365-2796.2009.02199.x

164. Persidsky Y, Ramirez SH, Haorah J, Kanmogne GD. Blood-brain Barrier: Structural Components and Function Under Physiologic and Pathologic Conditions. J Neuroimmune Pharmacol (2006) 1(3):223-36. doi: 10.1007/ s11481-006-9025-3

165. Lee T-H, Avraham H, Lee S-H, Avraham S. Vascular Endothelial Growth Factor Modulates Neutrophil Transendothelial Migration via Up-Regulation of Interleukin-8 in Human Brain Microvascular Endothelial Cells. J Biol Chem (2002) 277(12):10445-51. doi: 10.1074/jbc.M107348200

166. Michiels C. Endothelial Cell Functions. J Cell Physiol (2003) 196(3):430-43. doi: $10.1002 /$ jcp. 10333

167. Ramos-Cejudo J, Gutiérrez-Fernández M, Otero-Ortega L, Rodríguez-Frutos B, Fuentes B, Vallejo-Cremades MT, et al. Brain-Derived Neurotrophic Factor Administration Mediated Oligodendrocyte Differentiation and Myelin Formation in Subcortical Ischemic Stroke. Stroke (2015) 46 (1):221-8. doi: 10.1161/STROKEAHA.114.006692

168. Gosk S, Vermehren C, Storm G, Moos T. Targeting Anti-Transferrin Receptor Antibody (OX26) and OX26-Conjugated Liposomes to Brain Capillary Endothelial Cells Using In Situ Perfusion. J Cereb Blood Flow Metab (2004) 24(11):1193-204. doi: 10.1097/01.WCB.0000135592.28823.47

169. Bondy CA, Cheng CM. Signaling by Insulin-Like Growth Factor 1 in Brain. Eur J Pharmacol (2004) 490(1-3):25-31. doi: 10.1016/j.ejphar.2004.02.042

170. Didier N, Romero IA, Créminon C, Wijkhuisen A, Grassi J, Mabondzo A. Secretion of Interleukin-1 $\beta$ by Astrocytes Mediates Endothelin-1 and Tumour Necrosis Factor- $\alpha$ Effects on Human Brain Microvascular Endothelial Cell Permeability. J Neurochem (2003) 86(1):246-54. doi: 10.1046/j.1471-4159.2003.01829.x

171. Kimura C, Oike M, Ohnaka K, Nose Y, Ito Y. Constitutive Nitric Oxide Production in Bovine Aortic and Brain Microvascular Endothelial Cells: A Comparative Study. J Physiol (2004) 554(3):721-30. doi: 10.1113/ jphysiol.2003.057059 
172. Katona É, Settakis G, Varga Z, Juhász M, Paragh G, Bereczki D, et al. Both Nitric Oxide and Endothelin-1 Influence Cerebral Blood Flow Velocity at Rest and After Hyper-and Hypocapnic Stimuli in Hypertensive and Healthy Adolescents. Kidney Blood Pressure Res (2006) 29(3):152-8. doi: 10.1159/ 000095348

173. Müller M, Schwerdtfeger K, Maier B, Mautes A, Schiedat T, Bianchi O, et al. Cerebral Blood Flow Velocity and Inflammatory Response After Severe Traumatic Brain Injury. Eur J Ultrasound (2001) 12(3):203-8. doi: 10.1016/ S0929-8266(00)00118-X

174. Bauer B, Hartz AM, Miller DS. Tumor Necrosis Factor $\alpha$ and Endothelin-1 Increase P-Glycoprotein Expression and Transport Activity at the Blood-Brain Barrier. Mol Pharmacol (2007) 71(3):667-75. doi: 10.1124/mol.106.029512

175. Hung VK, Yeung PK, Lai AK, Ho MC, Lo AC, Chan KC, et al. Selective Astrocytic Endothelin-1 Overexpression Contributes to Dementia Associated With Ischemic Stroke by Exaggerating Astrocyte-Derived Amyloid Secretion. J Cereb Blood Flow Metab (2015) 35(10):1687-96. doi: 10.1038/jcbfm.2015.109

176. Tsang MC, Lo AC, Cheung PT, Chung SS, Chung SK. Perinatal Hypoxia-/ Ischemia-Induced Endothelin-1 mRNA in Astrocyte-Like and Endothelial Cells. Neuroreport (2001) 12(10):2265-70. doi: 10.1097/00001756-200107200-00044

177. Zhou Q-L, Strichartz G, Davar G. Endothelin-1 Activates ETA Receptors to Increase Intracellular Calcium in Model Sensory Neurons. Neuroreport (2001) 12(17):3853-7. doi: 10.1097/00001756-200112040-00050

178. Koyama Y, Tsujikawa K, Matsuda T, Baba A. Endothelin-1 Stimulates Glial Cell Line-Derived Neurotrophic Factor Expression in Cultured Rat Astrocytes. Biochem Biophys Res Commun (2003) 303(4):1101-5. doi: 10.1016/S0006-291X(03)00491-1

179. Dashwood MR, Tsui JC. Endothelin-1 and Atherosclerosis: Potential Complications Associated With Endothelin-Receptor Blockade. Atherosclerosis (2002) 160(2):297-304. doi: 10.1016/S0021-9150(01)00586-X

180. Lin C-C, Hsieh H-L, Shih R-H, Chi P-L, Cheng S-E, Yang C-M. UpRegulation of COX-2/PGE 2 by Endothelin-1 via MAPK-Dependent NF$\kappa \mathrm{b}$ Pathway in Mouse Brain Microvascular Endothelial Cells. Cell Communication Signaling (2013) 11(1):8. doi: 10.1186/1478-811X-11-8

181. Carter RA, Wicks IP. Vascular Cell Adhesion Molecule 1 (CD106): A Multifaceted Regulator of Joint Inflammation. Arthritis Rheum: Off J Am Coll Rheumatol (2001) 44(5):985-94. doi: 10.1002/1529-0131(200105) 44:5<985::AID-ANR176>3.0.CO;2-P

182. Zille M, Ikhsan M, Jiang Y, Lampe J, Wenzel J, Schwaninger M. The Impact of Endothelial Cell Death in the Brain and Its Role After Stroke: A Systematic Review. Cell Stress (2019) 3(11):330. doi: 10.15698/cst2019.11.203

183. Franceschini R, Gandolfo C, Cataldi A, Del Sette M, Rolandi A, Corsini G, et al. Twenty-Four-Hour Endothelin-1 Secretory Pattern in Stroke Patients. Biomed Pharmacother (2001) 55(5):272-6. doi: 10.1016/S0753-3322(01)00059-2

184. Hültner L, Ehrenreich H. Mast Cells and Endothelin-1: A Life-Saving Biological Liaison? Trends Immunol (2005) 26(5):235-8. doi: 10.1016/ j.it.2005.03.007

185. Sapira V, Cojocaru IM, Lilios G, Grigorian M, Cojocaru M. Study of Endothelin1 in Acute Ischemic Stroke. Rom J Intern Med (2010) 48(4):329-32.

186. Bates T, Loesch A, Burnstock G, Clark J. Immunocytochemical Evidence for a Mitochondrially Located Nitric Oxide Synthase in Brain and Liver. Biochem Biophys Res Commun (1995) 213(3):896-900. doi: 10.1006/ bbrc. 1995.2213

187. Suzuki N, Motohashi N, Uezumi A, Fukada S, Yoshimura T, Itoyama Y, et al. NO Production Results in Suspension-Induced Muscle Atrophy Through Dislocation of Neuronal NOS. J Clin Invest (2007) 117(9):2468-76. doi: 10.1172/JCI30654

188. Madrigal JL, Hurtado O, Moro MA, Lizasoain I, Lorenzo P, Castrillo A, et al. The Increase in TNF- $\alpha$ Levels Is Implicated in NF- $\mathrm{Kb}$ Activation and Inducible Nitric Oxide Synthase Expression in Brain Cortex After Immobilization Stress. Neuropsychopharmacology (2002) 26(2):155-63. doi: 10.1016/S0893-133X(01)00292-5

189. Chen J, Zacharek A, Zhang C, Jiang H, Li Y, Roberts C, et al. Endothelial Nitric Oxide Synthase Regulates Brain-Derived Neurotrophic Factor Expression and Neurogenesis After Stroke in Mice. J Neurosci (2005) 25 (9):2366-75. doi: 10.1523/JNEUROSCI.5071-04.2005

190. Sanz MJ, Hickey MJ, Johnston B, McCafferty DM, Raharjo E, Huang PL, et al. Neuronal Nitric Oxide Synthase (NOS) Regulates Leukocyte-
Endothelial Cell Interactions in Endothelial NOS Deficient Mice. $\mathrm{Br}$ Pharmacol (2001) 134(2):305-12. doi: 10.1038/sj.bjp.0704234

191. Endres M, Laufs U, Liao JK, Moskowitz MA. Targeting eNOS for Stroke Protection. Trends Neurosci (2004) 27(5):283-9. doi: 10.1016/ j.tins.2004.03.009

192. Whitehead SN, Cheng G, Hachinski VC, Cechetto DF. Progressive Increase in Infarct Size, Neuroinflammation, and Cognitive Deficits in the Presence of High Levels of Amyloid. Stroke (2007) 38(12):3245-50. doi: 10.1161/ STROKEAHA.107.492660

193. Reuter B, Rodemer C, Grudzenski S, Meairs S, Bugert P, Hennerici MG, et al. Effect of Simvastatin on MMPs and TIMPs in Human Brain Endothelial Cells and Experimental Stroke. Trans Stroke Res (2015) 6(2):156-9. doi: 10.1007/s12975-014-0381-7

194. Park MH, Lee JY, Park KH, Jung IK, Kim K-T, Lee Y-S, et al. Vascular and Neurogenic Rejuvenation in Aging Mice by Modulation of ASM. Neuron (2018) 100(1):167-182. e9. doi: 10.1016/j.neuron.2018.09.010

195. Tasaki A, Shimizu F, Sano Y, Fujisawa M, Takahashi T, Haruki H, et al. Autocrine MMP-2/9 Secretion Increases the BBB Permeability in Neuromyelitis Optica. J Neurol Neurosurg Psychiatry (2014) 85(4):419-30. doi: 10.1136/jnnp-2013-305907

196. Almeida A, Delgado-Esteban M, Bolanos JP, Medina JM. Oxygen and Glucose Deprivation Induces Mitochondrial Dysfunction and Oxidative Stress in Neurones But Not in Astrocytes in Primary Culture. J Neurochem (2002) 81(2):207-17. doi: 10.1046/j.1471-4159.2002.00827.x

197. Rana S, Dringen R. Gap Junction Hemichannel-Mediated Release of Glutathione From Cultured Rat Astrocytes. Neurosci Lett (2007) 415 (1):45-8. doi: 10.1016/j.neulet.2006.12.043

198. Liang J, Takeuchi H, Doi Y, Kawanokuchi J, Sonobe Y, Jin S, et al. Excitatory Amino Acid Transporter Expression by Astrocytes Is Neuroprotective Against Microglial Excitotoxicity. Brain Res (2008) 1210:11-9. doi: 10.1016/j.brainres.2008.03.012

199. Fuente-Martín E, García-Cáceres C, Granado M, de Ceballos ML, SánchezGarrido MÁ, Sarman B, et al. Leptin Regulates Glutamate and Glucose Transporters in Hypothalamic Astrocytes. J Clin Invest (2012) 122(11):390013. doi: $10.1172 / \mathrm{JCI} 64102$

200. Wang Q, van Hoecke M, Tang XN, Lee H, Zheng Z, Swanson RA, et al. Pyruvate Protects Against Experimental Stroke via an Anti-Inflammatory Mechanism. Neurobiol Dis (2009) 36(1):223-31. doi: 10.1016/j.nbd.2009.07.018

201. Li L, Lundkvist A, Andersson D, Wilhelmsson U, Nagai N, Pardo AC, et al. Protective Role of Reactive Astrocytes in Brain Ischemia. J Cereb Blood Flow Metab (2008) 28(3):468-81. doi: 10.1038/sj.jcbfm.9600546

202. Sarafian TA, Montes C, Imura T, Qi J, Coppola G, Geschwind DH, et al. Disruption of Astrocyte STAT3 Signaling Decreases Mitochondrial Function and Increases Oxidative Stress In Vitro. PloS One (2010) 5(3):e9532. doi: 10.1371/journal.pone.0009532

203. Sofroniew MV. Astrocyte Barriers to Neurotoxic Inflammation. Nat Rev Neurosci (2015) 16(5):249-63. doi: 10.1038/nrn3898

204. David Y, Cacheaux LP, Ivens S, Lapilover E, Heinemann U, Kaufer D, et al. Astrocytic Dysfunction in Epileptogenesis: Consequence of Altered Potassium and Glutamate Homeostasis? J Neurosci (2009) 29(34):1058899. doi: 10.1523/JNEUROSCI.2323-09.2009

205. KIRYUSHKO D, Berezin V, Bock E. Regulators of Neurite Outgrowth: Role of Cell Adhesion Molecules. Ann New York Acad Sci (2004) 1014(1):140-54 doi: 10.1196/annals.1294.015

206. Muhammad S, Haasbach E, Kotchourko M, Strigli A, Krenz A, Ridder DA, et al. Influenza Virus Infection Aggravates Stroke Outcome. Stroke (2011) 42 (3):783-91. doi: 10.1161/STROKEAHA.110.596783

207. Sharma V, Ling TW, Rewell SS, Hare DL, Howells DW, Kourakis A, et al. A Novel Population of $\alpha$-Smooth Muscle Actin-Positive Cells Activated in a Rat Model of Stroke: An Analysis of the Spatio-Temporal Distribution in Response to Ischemia. J Cereb Blood Flow Metab (2012) 32(11):2055-65. doi: 10.1038/jcbfm.2012.107

208. Ohkawa Y, Momota H, Kato A, Hashimoto N, Tsuda Y, Kotani N, et al. Ganglioside GD3 Enhances Invasiveness of Gliomas by Forming a Complex With Platelet-Derived Growth Factor Receptor $\alpha$ and Yes Kinase. J Biol Chem (2015) 290(26):16043-58. doi: 10.1074/jbc.M114.635755

209. Fisher M. Pericyte Signaling in the Neurovascular Unit. Stroke (2009) 40 (3_suppl_1):S13-5. doi: 10.1161/STROKEAHA.108.533117 
210. Chen Y, Li Q, Tang J, Feng H, Zhang JH. The Evolving Roles of Pericyte in Early Brain Injury After Subarachnoid Hemorrhage. Brain Res (2015) 1623:110-22. doi: 10.1016/j.brainres.2015.05.004

211. Nissou M-F, Guttin A, Zenga C, Berger F, Issartel J-P, Wion D. Additional Clues for a Protective Role of Vitamin D in Neurodegenerative Diseases: 1, 25-Dihydroxyvitamin D3 Triggers an Anti-Inflammatory Response in Brain Pericytes. J Alzheimer's Dis (2014) 42(3):789-99. doi: 10.3233/JAD-140411

212. Bell RD, Winkler EA, Sagare AP, Singh I, LaRue B, Deane R, et al. Pericytes Control Key Neurovascular Functions and Neuronal Phenotype in the Adult Brain and During Brain Aging. Neuron (2010) 68(3):409-27. doi: 10.1016/ j.neuron.2010.09.043

213. Sweeney MD, Ayyadurai S, Zlokovic BV. Pericytes of the Neurovascular Unit: Key Functions and Signaling Pathways. Nat Neurosci (2016) 19 (6):771-83. doi: 10.1038/nn.4288

214. Hurtado-Alvarado G, Cabañas-Morales AM, Gómez-Gónzalez B. Pericytes: Brain-Immune Interface Modulators. Front Integr Neurosci (2014) 7:80. doi: 10.3389/fnint.2013.00080

215. Ribatti D, Nico B, Crivellato E. The Role of Pericytes in Angiogenesis. Int $J$ Dev Biol (2011) 55(3):261-8. doi: 10.1387/ijdb.103167dr

216. Mills SJ, Cowin AJ, Kaur P. Pericytes, Mesenchymal Stem Cells and the Wound Healing Process. Cells (2013) 2(3):621-34. doi: 10.3390/cells2030621
217. Fernández-Klett F, Priller J. Diverse Functions of Pericytes in Cerebral Blood Flow Regulation and Ischemia. J Cereb Blood Flow Metab (2015) 35(6):8837. doi: $10.1038 / \mathrm{jcbfm} .2015 .60$

Conflict of Interest: The authors declare that the research was conducted in the absence of any commercial or financial relationships that could be construed as a potential conflict of interest.

Publisher's Note: All claims expressed in this article are solely those of the authors and do not necessarily represent those of their affiliated organizations, or those of the publisher, the editors and the reviewers. Any product that may be evaluated in this article, or claim that may be made by its manufacturer, is not guaranteed or endorsed by the publisher.

Copyright $(2021$ Shaheryar, Khan, Adnan, Zaidi, Hänggi and Muhammad. This is an open-access article distributed under the terms of the Creative Commons Attribution License (CC BY). The use, distribution or reproduction in other forums is permitted, provided the original author(s) and the copyright owner(s) are credited and that the original publication in this journal is cited, in accordance with accepted academic practice. No use, distribution or reproduction is permitted which does not comply with these terms. 